LBNL-57318

\title{
Market Failures, Consumer Preferences, and Transaction Costs in Energy Efficiency Purchase Decisions
}

\author{
Jayant Sathaye and Scott Murtishaw \\ International Energy Studies \\ Energy Analysis Department \\ Environmental Energy Technologies Division \\ Lawrence Berkeley National Laboratory \\ Berkeley, CA 94720 \\ Prepared for the California Energy Commission \\ Public Interest Energy Research \\ Sacramento, CA
}

November 23, 2004

This work was supported by the Public Interest Energy Research program of the California Energy Commission through the U.S. Department of Energy under Contract No. DE- AC03-76SF00098

Downloadable from http://eetd.lbl.gov/ea/ies/ieua/Pubs.html 



\begin{abstract}
Several factors limit the energy savings potential and increase the costs of energyefficient technologies to consumers. These factors may usefully be placed into two categories; one category is what economists would define as market failures and the other is related to consumer preferences. This paper provides a conceptual framework for understanding the roles of these factors, and develops a methodology to quantify their effects on costs and potentials of two energy efficient end uses - residential lighting and clothes washers. It notes the significant roles played by the high implicit cost of obtaining information about the benefits of the two technologies and the apparent inability to process and utilize information. For compact fluorescent lamps, this report finds a conservative estimate of the cost of conserved energy of 3.1 cents per kWh. For clothes washers, including water savings reduces the cost of conserved energy from 13.6 cents to 4.3 cents per equivalent kWh. Despite these benefits, market share remains low. About 18 million tons of $\mathrm{CO}_{2}$ could be saved cost effectively from 2005 sales of these two technologies alone. The paper also notes that trading of carbon emissions will incur transaction costs that will range from less than 10 cents per metric ton of $\mathrm{CO}_{2}$ for larger size projects and programs to a few dollars per metric ton of carbon for the smaller ones.
\end{abstract}





\section{Executive Summary}

Two general approaches have been used for the assessment of energy demand and supply - the so-called "bottom-up" and "top-down" approaches. The bottom-up approach focuses on individual technologies for delivering energy services, such as household durable goods and industrial process technologies. The top-down method assumes a general equilibrium or macroeconomic perspective, wherein costs are defined in terms of changes in economic output, income, or GDP, typically from the imposition of energy or emissions taxes.

The bottom-up approach assumes that various factors prevent consumers from taking actions that would be in their private self-interest, that is, would result in the provision of energy services at lower cost. These factors include lack of information about energy efficiency opportunities, lack of access to capital to finance energy efficiency investment, misplaced incentives which separate responsibilities for making capital investments and paying operating costs, hidden costs, transaction costs, bounded rationality, and product unavailability.

The thrust of this work thus focuses on the development of a bottom-up approach that (1) accounts for all costs of a mitigation option, including non-energy and transaction costs, and (2) allows for representation of the impact of each factor on a cost component and/or the penetration level of a mitigation option. We focus on energy efficiency options and the representation of their marginal cost curves, typically referred to as cost of conserved energy (CCE) curves, using the costs and benefits faced by consumers.

We illustrate the use of our factors approach by demonstrating its application to two residential building technologies - CFLs and clothes washers. These technologies are characterized by differing levels of financial investment as well as differing degrees of portability. Thus, each technology is affected by a slightly different set of the factors enumerated above. Note that the values used for various parameters (particularly for the implicit information and preference costs) are entirely hypothetical. The focus of this study is less on quantitative results and more on the application of the methodological approach.

In California, the market share of CFLs for residential use was $1 \%$ or less until the electricity crisis in 2001 when the share jumped to about $6 \%$ for the year. Since 2001, the market share of CFLs has fallen to between 4\% and 5\% per year (Itron, 2004). Given the energy savings CFLs provide, their slow penetration into the residential lighting market would be difficult to explain. To derive an estimate of cumulative penetration we calculated the number of CFLs purchased in the eight years (the approximate lifespan of a CFL used 2.5 hours per day) prior to 2005 using data from Itron (2004). The result is that by 2005, a cumulative $21 \%$ of all fixtures are assumed to be using CFLs.

Figure ES-1 shows estimated lifetime GHG savings from purchase of CFLs in 2005.The total length of the curve represents the possible savings if the entire eligible stock were to be switched to CFLs in 2005. From left to right, the points along the curve show how each barrier diminishes the potential savings and the impact of each barrier on the CCE. 
The first several factors are all deemed to affect the eligible stock of fixtures without necessarily impacting the expected costs and benefits. For example, an assumed $1 \%$ of households have their electric service included in their rent (i.e. are not separately metered) reduces the number of households due to split incentives. Other costless factors include "lock-in," meaning that CFLs could not fit into some fixtures originally designed for incandescent bulbs, and product availability.

The first factor affecting the CCE is the possibility that some CFLs may not last as long as claimed. We reduced the expected lifetime of CFLs from 8,000 hours to 6,000 hours and recalculated the costs and benefits. The next three factors represent transaction costs and implicit costs. For these three factors - product information cost, vendor information cost, and consumer preferences - we added $\$ 10, \$ 5$, and $\$ 5$ respectively to the "price" of the bulb. The consumer preference factor represents the fact that many consumers may simply prefer the familiar shape of incandescent bulbs as well as the warmer light they emanate, and for this we also added $\$ 5$ to the cost of the bulb.

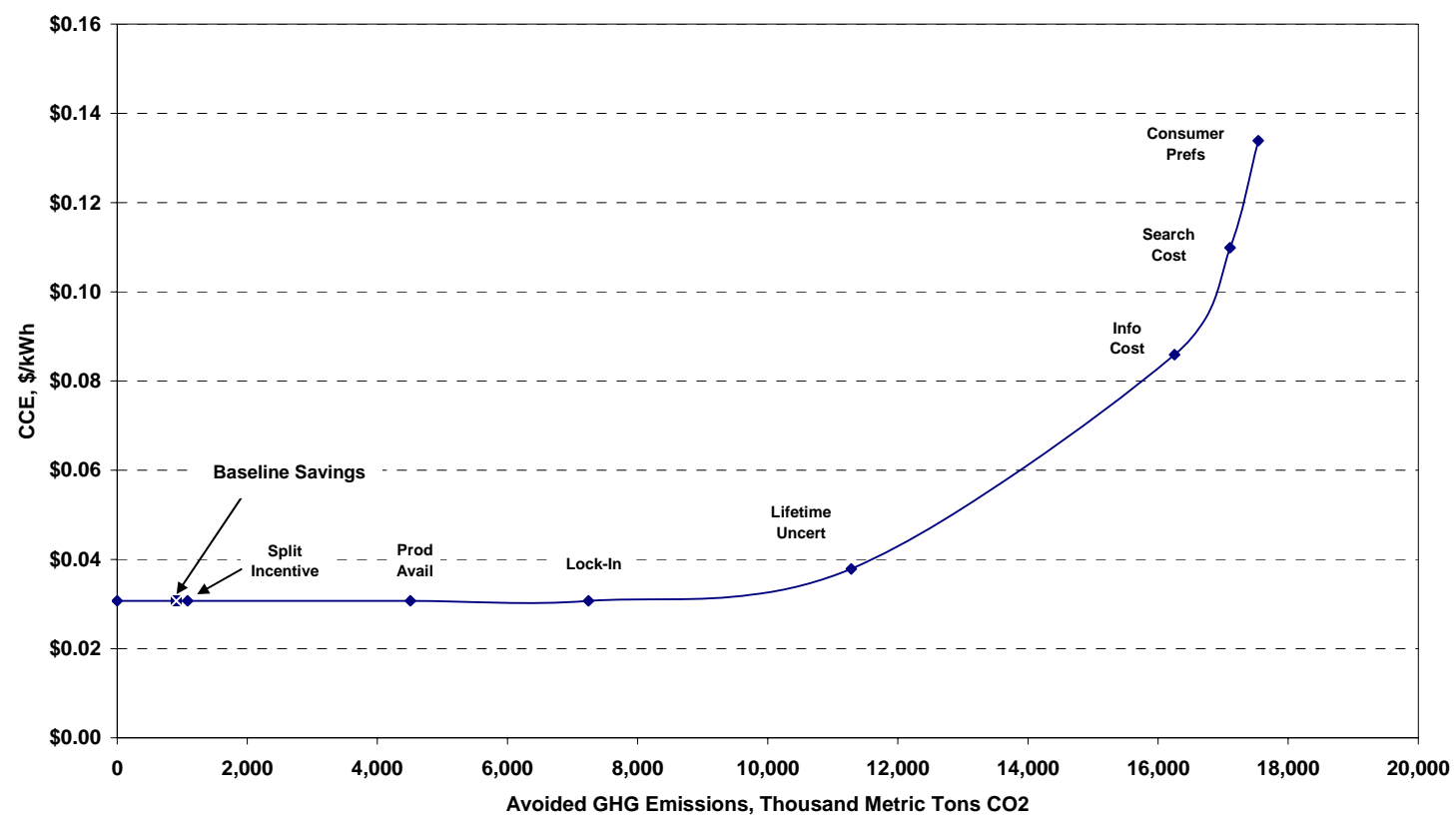

Figure ES-1. Supply Curve of Savings Potential from CFLs Adjusted for Impact of Factors

Unlike conventional conserved energy supply curves, which are composed of multiple measures whose quantities are unresponsive to price, this curve depicts one measure for which the expected savings (and CCE) increase as individual factors come into play. Given the costs and benefits of CFLs, the substantial implicit information cost must be added in order to drive market share down to current actual levels. Figure ES- 1 shows that even with implicit costs taken into account, CFLs purchased in 2005 could costeffectively reduce over 16,000 metric tons of $\mathrm{CO}_{2}$ over their lifetimes. 
The next technology chosen was resource efficient clothes washers. Most of the energy savings from efficient washers is due to avoided energy use from reduction of hot water consumption. Several factors beyond those affecting CFLs limit penetration of resource efficient washers. First, since washers will generally last 10 to 15 years and will not be replaced before their useful life is over. Thus, only a fraction of the stock is turning over during any given year. Second, many households do not have washer and dryer hook-ups. Third, major appliances are often provided in many rental units that do have washer and dryer hook-ups.

The inclusion of non-energy benefits has a crucial impact on the cost-effectiveness of resource efficient washers. The initial weighted average CCE for all households when water savings are not counted is $\$ 0.136$, compared to $\$ 0.049$ when they are included.

Resource efficient washers are significantly more cost-effective for those using electricheated water due to the higher cost per unit of energy for electricity. For example, although the initial CCEs for washers using gas and electric-heated water in high-income households are virtually the same ( $\$ 0.016$ and $\$ 0.017$ respectively), the benefit-cost ratios differ significantly due to the reduced benefit of saving a cheaper fuel (1.4 versus 2.5).

The demand for residential washers in 2005 was estimated at 817,977 units, the sum of replacements for retired washers $(717,661)$ and washers for new housing stock $(100,316)$. In addition to dividing the households based on type of water heating, households were also separated by income. This is due to differences in the costs of water and power among income groups, the differing shares of residency in units with washer/dryer hookups, and the fact that some lower income households may not be able to secure credit for the resource efficient washer.

Figure ES-2 depicts the results of our analysis. This figure includes two curves, one showing the estimated CCE and savings potential when water savings benefits are included and the other where they are not. The curve that includes water benefits shows that even accounting for baseline savings, over 700 thousand metric tons of $\mathrm{CO}_{2}$ can be avoided cost-effectively. After the baseline share is taken into account, the estimated impact of split incentives has a large effect on the savings potential. Moving to the right of the curve, our estimates of various information costs are shown to have a large impact on the CCE and, therefore, on the adoption of the resource efficient washers. 


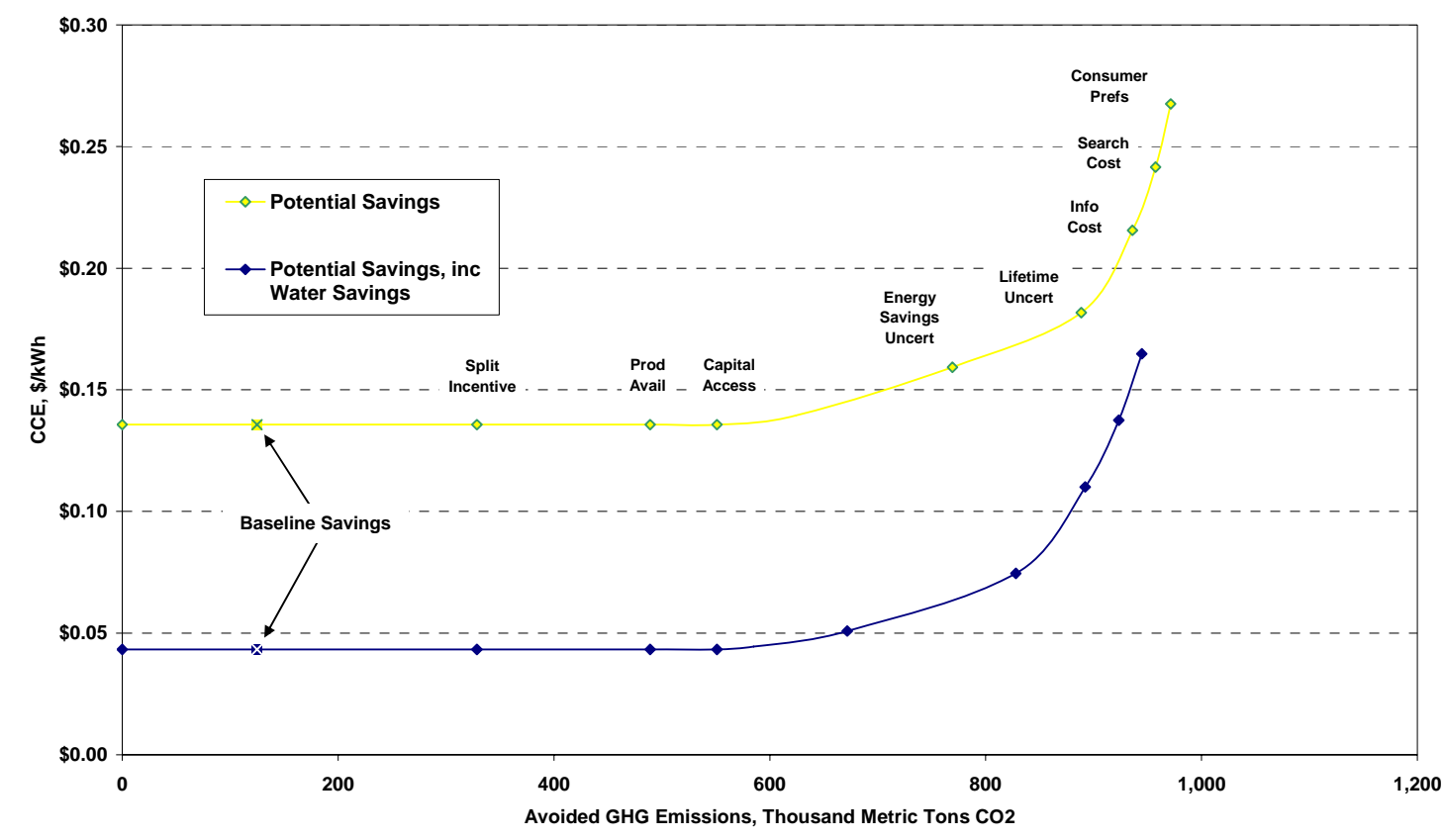

Figure ES-2. Supply Curve of Savings Potential from Resource Efficient Washers Adjusted for Impact of Market Factors

For all measures, high implicit information costs were required to reduce adoption of the measures we examined to near current levels. While some factors such as split incentives, product availability, and lock-in may reduce adoption significantly, it is difficult to explain the rest of the gap between cost-effective potential and current penetration rates. Cognitive limitations on gathering and processing information may account for much of this gap. This suggests that government interventions to reduce information and transaction costs can significantly increase diffusion of resource efficient products. The use of minimum performance standards offers a powerful policy remedy to overcoming virtually all of the barriers that we have enumerated. Unlike information collection and dissemination programs, standards also provide a means of resolving the split-incentive barrier. Rigorous washing machine standards are set to take effect in California beginning in 2007, becoming stricter in 2010. These standards will significantly improve water and energy efficiency for washers sold in California. Based on our rough analysis, this standard should be cost-effective for most classes of consumers in California. These estimates are very sensitive to two factors: the initial cost of the resource efficient washers and the number of loads the machines are used for each week. If the cost of a base model resource efficient washer drops just $10 \%$ below the price used in our example, they would be cost-effective for all customers. ${ }^{1}$ Resource efficient washers may also not be cost-effective in some cases for smaller households that use their machines fewer than eight times per week. However, the application of standards requires careful analysis, and in some cases low-income households may need financial assistance to comply.

\footnotetext{
${ }^{1}$ Due to economies of scale and technological progress, the price of many energy efficient appliances has often fallen after the application of minimum performance standards (Dale et al., 2002).
} 


\section{Table of Contents}

List of Figures and Tables.......................................................................................... vi

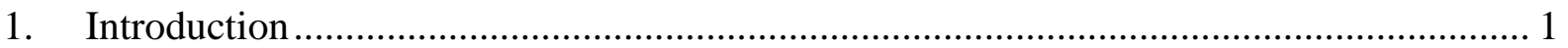

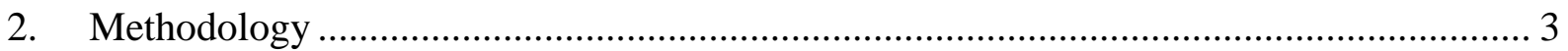

3. Factors, Potentials and Transaction Costs............................................................ 5

4. Analysis of Factors Affecting CFLs and Clothes Washers.......................................... 8

4.1 Xenergy Study on California Efficiency Potential............................................. 8

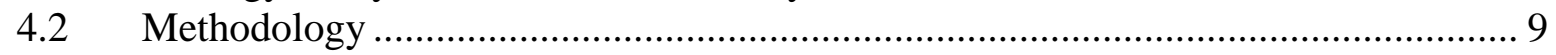

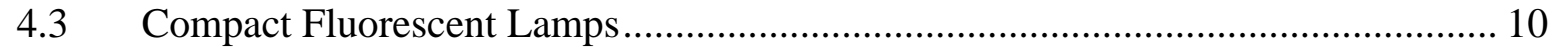

4.3.1 Parameter Values for Calculating the CCE................................................ 11

4.3.2 Calculation of the Initial Stock .................................................................. 12

4.3.3 Analysis of the Impact of Factors ............................................................ 12

4.4 Resource Efficient Clothes Washers.................................................................. 18

4.4.1 Parameter Values for Calculating the CCE............................................... 18

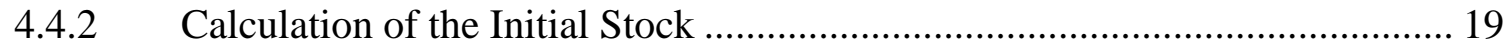

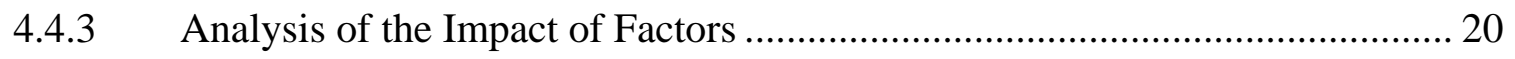

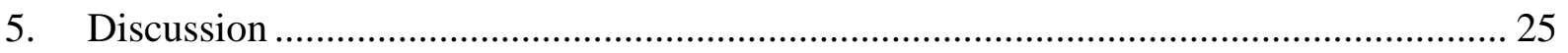

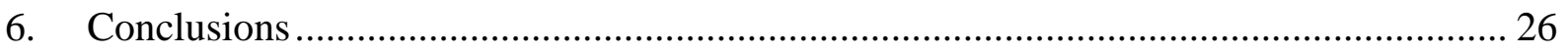

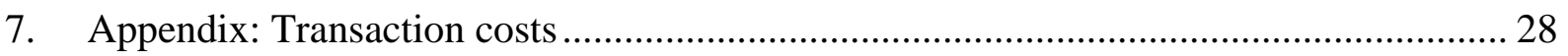

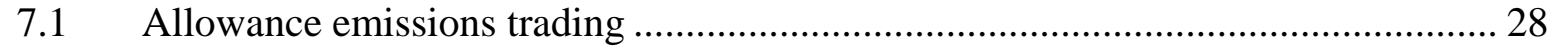

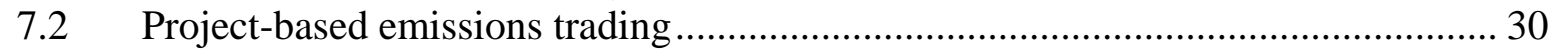




\section{List of Figures and Tables}

Figure 1. Penetration of mitigation technologies: A conceptual framework ............................... 7

Figure 2. Correspondence of Xenergy and Berkeley Lab Savings Potentials and Factors........... 10

Figure 3. Supply Curve of Savings Potential from CFLs Adjusted for Impact of Factors........... 16

Figure 4. Supply Curve of Savings Potential from Resource Efficient Washers Adjusted for

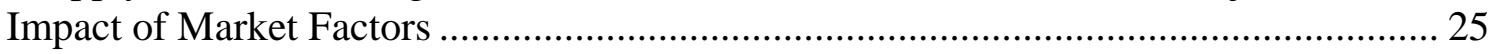

Table 1. Parameter Values for Calculating the CCE and Benefits for CFLs............................ 12

Table 2. Effect of Market Factors on CFL Sales in California in 2005 (18W CFL vs. 75W Incandescent Bulb Used 2.5 Hours per Day) ....................................................... 15

Table 3. Parameter Values for Calculating the CCE for Resource Efficient Washers ................ 19

Table 4. Effect of Market Factors on Resource Efficient Washing Machine Sales in California 23

Table 5. Selected emissions trading and project based schemes ............................................ 29

Table 6. Transaction costs reported in selected studies ....................................................... 31 


\section{Introduction}

Two general approaches have been used for the assessment of energy demand and supply the so-called "bottom-up" and "top-down" approaches. The bottom-up approach focuses on individual technologies for delivering energy services, such as household durable goods and industrial process technologies. For such technologies, the approach attempts to estimate the costs and benefits associated with investments in increased energy efficiency, often in the context of reductions in greenhouse gas (GHG) emissions or other environmental impacts. The top-down method assumes a general equilibrium or macroeconomic perspective, wherein costs are defined in terms of changes in economic output, income, or GDP, typically from the imposition of energy or emissions taxes. The California Energy Commission for instance is sponsoring work on the development of a top-down model in order to estimate the economic impacts on California of mitigation options to address climate change.

The fundamental difference between the two types of approaches is in the perspective taken by each on consumer and firm behavior and the performance of markets for energy efficiency. The bottom-up approach assumes that various factors (often referred to as "market barriers" in the energy efficiency literature) prevent consumers from taking actions that would be in their private self-interest, that is, would result in the provision of energy services at lower cost. These factors include lack of information about energy efficiency opportunities, lack of access to capital to finance energy efficiency investment, misplaced incentives which separate responsibilities for making capital investments and paying operating costs. In contrast, the top-down approach generally assumes that consumers and firms correctly perceive, and act in, their private self-interest (are utility and profit maximizers), and that unregulated markets serve to deliver optimal investments in energy efficiency as a function of prevailing prices. In this view, any market inefficiencies pertaining to energy efficiency result solely from the presence of environmental externalities that are not reflected in market prices.

In general, an assessment carried out using the bottom-up approach will very likely show significantly lower costs for meeting a given objective - e.g., a limit on carbon emissions than will one using a top-down approach. To some extent, the differences may lie in a failure of bottom-up studies to accurately account for all costs associated with implementing specific actions. Top-down methods, on the other hand, can fail to account realistically for consumer and producer behavior by relying too heavily on aggregate data (Krause et al., 1993). In addition, some top-down methods sacrifice sectoral and technology detail in return for being able to solve for general equilibrium resource allocations. Finally, top-down methods often ignore the fact that economies depart significantly from the stylized equilibria represented by the methods (Boero et al., 1991). Each approach, however, captures costs or details on technologies, consumer behavior, or impacts that the other does not. Consequently, a comprehensive assessment should combine elements of each approach to ensure that all relevant costs and impacts are accounted for.

Earlier studies have made efforts to explain the apparent discrepancies between energy efficiency opportunities and their market penetration levels (Blumstein et al., 1980), enumerated lists of barriers (Reddy, 1991 and Koomey, 1989), discovered and documented new barriers (Ruderman, 1987), established that opportunities vary by income groups (Koomey, 1995), noted the role of immature markets (Jaffe and Stavins, 1994a), and shown 
that equivalent products are cost effective even after accounting for hidden costs (Koomey and Sanstad, 1994). Recent electricity supply shortages have prompted analysts to examine the potential for energy efficiency in California (Rufo and Coito, 2002). The above body of work, however, lacks three important elements, one is the limited effort to develop a conceptual economic framework to explain the role of specific factors, second is the lack of quantification of transaction costs, and the third is the lack of quantification of the impact of these factors on cost components and/or penetration levels.

The thrust of this work thus focuses on the development of an approach that (1) accounts for all costs of a mitigation option, including non-energy and transaction costs, and (2) allows for representation of the impact of each factor on a cost component and/or the penetration level of a mitigation option. In so doing, the approach presents costs and penetration levels in a marginal cost curve format that is comparable to those used in top-down models. By focusing on the contribution of an individual factor or opportunity and its contribution to cost elements and penetration level, the approach allows for the development of transparent policies and programs that may be targeted at selected factors. It is a basic tenet of policy making that policies should be narrowly tailored to the problem at hand. This is both to increase the effectiveness of the policy response, as well as to avoid unintended consequences (Bardach, 2000). By disentangling the contribution of specific factors, we hope to offer an approach that will aid government agencies and utilities to maximize their efforts to stimulate the market for cost-effective energy efficient technologies.

Both top-down and bottom-up modeling approaches have traditionally assumed that transactions required to achieve emissions reductions are costless, or at the very least these are not explicitly represented in the models. A consequence is that models may be underreporting the cost of achieving mitigation reductions. Transaction costs comprise a large share of the factors affecting diffusion of new technologies and typically include those for search, negotiation, insurance, government approval, monitoring and verification, etc. These are incurred in all types of transactions but for our purposes these may be classified into two categories. One category includes costs of GHG emissions trading, similar to those incurred in the implementation of SOx and NOx programs. GHG emissions trading is a key feature of global models that seek to estimate the costs of GHG emissions reductions worldwide rather than in a country or region. A second category includes costs incurred in administering and implementing programs and policies to promote energy efficiency and/or other mitigation options. We report briefly on the costs of the first type of activity and their significance on the costs of reducing emissions.

This report is organized in several sections. The next section (Section 2) reports on earlier studies on the development of marginal cost curves, including the effect of factors, for California. It also describes the cost framework that has been developed to support the calculation of the cost of conserved energy (CCE) of energy-efficient devices. The approach used for this study modifies earlier approaches, which is described in this section. Section 3 lists typical factors and ways these add to the transaction costs of mitigation options. Our analysis of two residential energy-saving technologies and the impact of the factors affecting their adoption is presented in Section 4. Section 5 discusses results of our study and Section 6 presents its conclusions. 


\section{Methodology}

The energy sector comprises the major energy demand sectors (industry, residential and commercial, transport, and agriculture), and the energy supply sector, which consists of resource extraction, conversion, and delivery of energy products. GHG emissions occur at various points in the sector, from resource extraction to end use, and accordingly, options for mitigation exist at various points.

The bottom-up approach involves the development of scenarios based on energy end uses and evaluation of specific technologies that can satisfy demands for energy services. One can compare technologies based on their relative cost to achieve a unit of GHG reduction and other features of interest. This approach gives equal weight to both energy supply and energy demand options. A variety of screening criteria, including indicators of cost-effectiveness as well as non-economic concerns, can be used to identify and assess promising options, which can then be combined to create one or more mitigation scenarios. Mitigation scenarios are evaluated against the backdrop of a baseline scenario, which simulates the events assumed to take place in the absence of mitigation efforts. Mitigation scenarios can be designed to meet specific emission reduction targets or to simulate the effect of specific policy interventions. The results of a bottom-up assessment can then be compared to a top-down analysis of the impacts of energy sector scenarios on the macro-economy.

In order to make the two comparable, however, it is necessary to place the cost curves used in the two approaches on a comparable footing. In this paper, we will focus on energy efficiency options and the representation of their marginal cost curves, typically referred to as cost of conserved energy (CCE) curves. CCE curves were developed about two decades ago to place energy efficiency cost estimates at a level comparable to that for supply-side options (Meier, 1982). A CCE curve is made up of a combination of several options and can be sector-specific or economy-wide. The California Energy Commission has sponsored work on the development of such cost curves for mitigation options in the energy and forestry sectors, as well as preliminary supply curves for agricultural soils and non- $\mathrm{CO}_{2}$ gases. The CCE is estimated for each mitigation option and plotted against its resulting energy or emissions savings. ${ }^{1}$ A combination of such calculations yields a curve of CCE for a suite of mitigation options. The CCE calculation is based on investment theory ${ }^{2}$, and the CCE is expressed as

$$
\begin{aligned}
& C C E=\frac{I \cdot q}{E S}--------------(1) \\
& q=\frac{d}{\left(1-(1+d)^{-n}\right)}
\end{aligned}
$$

\footnotetext{
${ }^{1}$ One criticism that has been directed at the calculation of CCEs is that they may err by aggregating across the entire stock, without differentiating costs and discount rates for various classes of consumers. We have tried to avoid this mistake in our clothes washer analysis below by disaggregating potential adopters by income.

${ }^{2}$ Stoft (1995) offers an alternative expression that avoids the problem of double counting due to dependence among measures on a curve. In this paper, we use the more traditional formula, since our purpose is to illustrate the effect of barriers on two measures, CFLs and clothes washers, that are independent of each other in terms of their impacts on energy savings.
} 
Where:

$C C E=$ Cost of energy savings for a mitigation option, in $\$ / \mathrm{kWh}$

$I=$ Capital cost $(\$)$

$q=$ Capital recovery factor $\left(\mathrm{yr}^{-1}\right)$

$\mathrm{ES}=$ Annual energy savings $(\mathrm{kWh} / \mathrm{yr})$

$d=$ discount rate

$n=$ lifetime of the option (years)

These savings are estimated by comparing the electricity use of an efficient and an inefficient end-use technology, a compact fluorescent lamp (CFL) vs. an incandescent bulb for example. The comparable device has to be such that it offers the same service in terms of the lumen output, color rendering, and robustness to quality of electricity supply. The above can expression can easily be converted to a cost of avoided GHGs by applying emission factors to the energy source affected. However, since this report focuses on consumer decision-making, costs are left in energy terms since these are the costs consumers actually face.

Earlier analyses of energy efficiency options typically ignored other effects of the implementation of such options. These effects include changes in labor, material, and other resource requirements that are often monetizable, and others such as reduced pollution due to decreased use of electricity and other fuels that may be more difficult to quantify, and in particular more difficult to attribute to a mitigation measure. Adding monetizable effects that are attributable to an energy efficiency option can increase or decrease the cost of conserved energy. A recent analysis of the steel industry for the US for instance shows that costs decline overall with the addition of labor and material benefits, but more importantly that the ranking of options changes such that an option ranked as $47^{\text {th }}$ on the basis of its CCE becomes the topranked option when these other benefits are included (Worrell, et al. 2004).

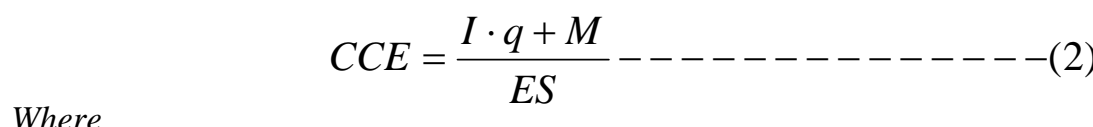

$M=$ Annual change in labor, material and other costs, and monetizable benefits ( $\$ / \mathrm{yr})$

In our illustrative analysis of two mitigation options, the clothes washers' option is particularly sensitive to the inclusion of water savings, and hence we use the expression in Equation 2 for calculating the CCE.

The CCE may be compared with the price of electricity to a consumer who owns or operates the device. If the CCE is lower than the electricity price the end-use device is considered to be cost effective.

The CCE may be estimated from different perspectives - residential consumer, utility company, and societal are those often used in analysis of the costs and benefits of energy efficiency policies and programs. An analysis from the consumer perspective focuses on the 
cost and savings as experienced by the consumer. Capital cost (I) in this case would include the typical incremental retail price difference between an efficient device and its more standard counterpart, including any additional taxes that a consumer would incur. The energy savings would be those that could be estimated on the basis of rated energy consumption. The discount rate would be equivalent to the rate at which the consumer would borrow funds for the purchase of the end-use appliance. The cost of borrowing (discount rate) may vary by the source of credit available to a consumer, which may be represented by income as a proxy variable. Where access to credit is in an issue, the rate may also vary by a consumer's location; urban vs. rural for instance. The CCE would be compared with the electricity tariff paid by the consumer.

From a societal perspective, the CCE estimation would be similar, except that no taxes would be added to the capital cost and the discount rate would be typically lower and based on the society's cost of borrowing funds; the tax-free rate on long-term bonds may be used as a proxy for this purpose. In place of the electricity tariff, the CCE would be compared with either the short- or long-run cost of avoided electricity supply, depending on whether the enduse or a combination of end-uses is too small to fall within the margin of error in estimation of future capacity needs, or large enough to result in monitorable avoidance of new generation and T\&D capacity.

The use of the above methodology requires estimation of the key input variables to the calculation of the CCE. These include capital cost, annual electricity savings, and other monetizable impacts, discount rate, and the lifetime of the device. In addition, in order to estimate total electricity savings from such devices, one needs to estimate the number of such devices that would penetrate the market over a defined time frame. The estimation or the use of assumed values, where data are lacking, which is typically the case, has been a source of controversy in the CCE calculation over many years (Golove and Eto, 1996). A typical supply schedule begins with zero cost that rises to denote an increase in marginal cost of supplying an increasingly scarce commodity. Analysts have often estimated the CCE of certain measures to begin with negative cost values that also rise with increasing energy savings. The negative cost implies that the end-use device should have penetrated the market in comparison to an energy inefficient device regardless of the price of electricity. Empirical observations clearly indicate however that such is not the case. This has led to the notion that "barriers" prevent the penetration of energy efficient devices that have either negative cost or cost less than the price of electricity supply.

\section{Factors, Potentials and Transaction Costs}

Earlier reports have enumerated lists of several factors (barriers) affecting the penetration of energy efficient devices by customer class or tariff category, region and/or sector (Reddy, 1991; Koomey and Brown, 1994; Golove and Eto, 1996; Eto, Prahl, and Schlegel, 1997; Sathaye and Bouille et al., 2001). These include lack of information, lack of access to capital, misplaced incentives, flaws in market structure, performance uncertainties, decisions influenced by custom and habits, inseparability of features, heterogeneity of consumers, hidden costs, transaction costs, bounded rationality, product unavailability, externalities, imperfect competition, etc. The extent of their inclusion affects both costs and the mitigation potential of a technology or a mix of technologies. Sathaye and Bouille (2001), following on 
the work of Jaffe and Stavins (1994) classify factors into two categories. The first category refers to factors that economists may typically classify as "market failures", the second to factors that are manifestations of consumer preferences, custom, cultural traits, habits, lifestyles, etc.

Associated with each category is the concept of potentials for GHG mitigation (Figure 1). Each concept of the potential represents a hypothetical projection that might be made today regarding the extent of GHG mitigation. The leftmost line, labeled market potential indicates the amount of GHG mitigation that might be expected to occur under forecast market conditions, with no changes in policy or implementation of measures whose primary purpose is the mitigation of GHGs. At the other extreme, the technical potential describes the maximum amount of GHG mitigation achievable through technology diffusion. This is a hypothetical projection of the extent of GHG mitigation that could be achieved over time if all technically feasible technologies were used in all relevant applications, without regard to their cost or user acceptability.

Definitionally, we can say that whatever physical, cultural, institutional, social, or human factors are preventing us from reaching the technical potential are barriers to the mitigation of GHG via technology diffusion. Since, however, our ultimate goal is to understand policy options for mitigation, it is useful to group these factors in a way that facilitates understanding the kinds of policies that would be necessary to overcome them. As we create these different categories of factors, we correspondingly create intermediate conceptions of the potential for GHG mitigation. Starting at the left, we can imagine addressing factors (often referred to as market failures) that relate to markets, public policies and other institutions that inhibit the diffusion of technologies that are (or are projected to be) cost-effective for users without reference to any GHG benefits they may generate. Amelioration of this class of market imperfections would increase GHG mitigation towards the level that is labeled as the economic potential. The economic potential represents the level of GHG mitigation that could be achieved if all technologies that are cost-effective from consumers' point of view were implemented. Because economic potential is evaluated from the consumer's point of view, we would evaluate cost-effectiveness using market prices and the private rate of time discounting, and also take into account consumers' preferences regarding the acceptability of the technologies' performance characteristics.

Some of the market failures listed above can be broadly grouped together as cognitive factors affecting product diffusion. By this, we mean that there are limitations to consumers' ability to gather and process information. Before any consumer can make the decision to adopt a technology, he or she must at a minimum be aware of its existence. Once aware, a consumer needs to make some effort to gather the information needed to make an informed decision about whether a given technology provides more benefits than it costs. In order to do this, an individual needs the analytic capacity to fairly accurately quantify the benefits and costs. Even an aware, informed, capable consumer must ultimately make the effort to assess benefits and costs before making the decision to adopt.

A consumer who has made the decision to adopt needs to find a vendor for the product in question. Relatively new technologies are likely to be less widely available than their more 
standard counterparts. Thus, limitations on cognitive resources are described by factors such as performance uncertainty, information costs, and bounded rationality.

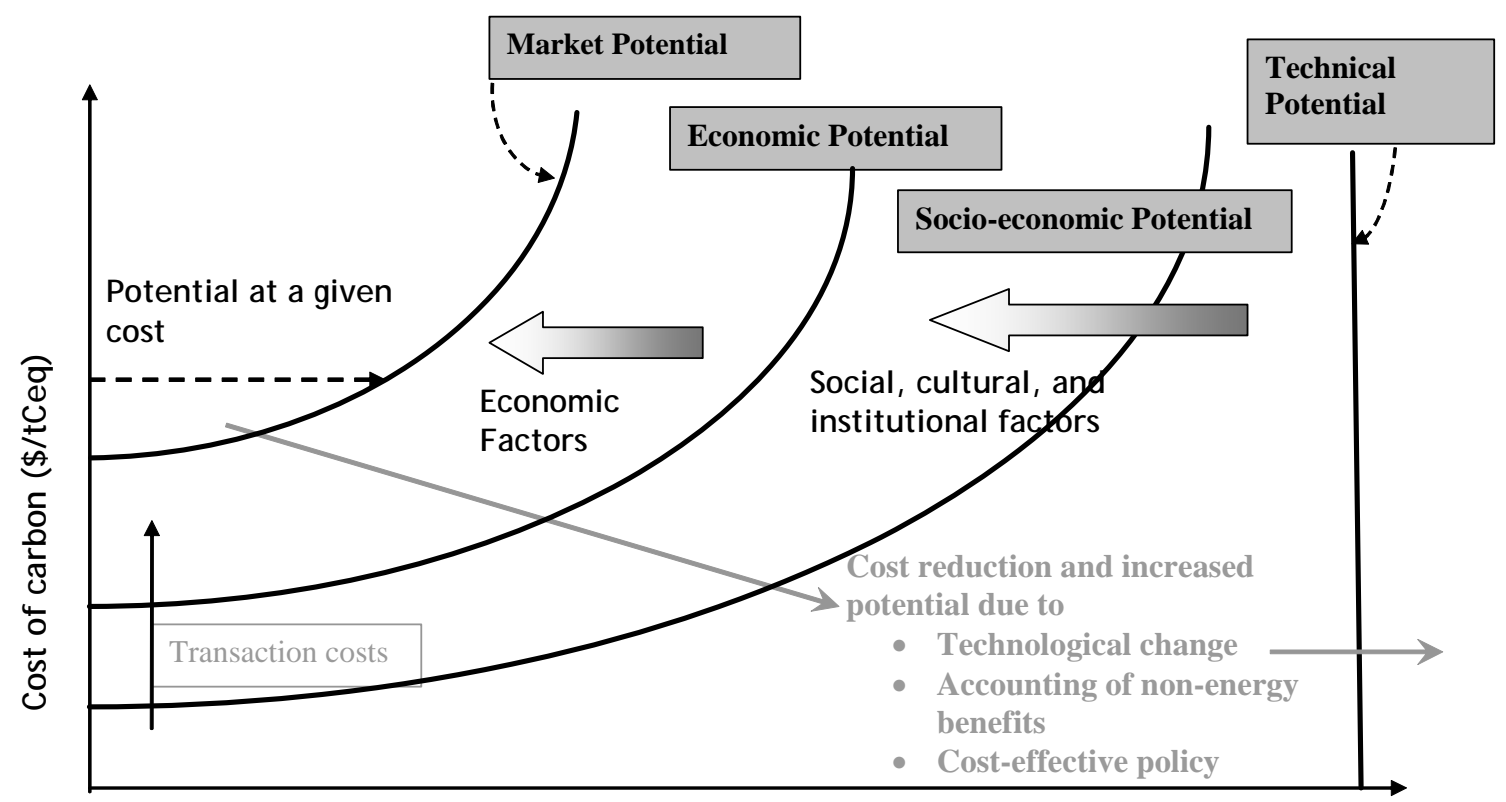

Figure 1. Penetration of mitigation technologies: A conceptual framework

Elimination of all of these market imperfections would not produce technology diffusion at the level of the technical potential. That is, even if these factors are removed, some GHGmitigating technologies may not be widely used simply because consumer preferences operate against their acceptance. These factors, which define the gap between economic potential and technical potential, are usefully placed in two groups separated by a socio-economic potential. The socio-economic potential represents the level of GHG mitigation that would be achieved if all technologies that are cost effective on the basis of using a social, rather than a private, rate of discount, including externalities, with the use of appropriate prices devoid of taxes and subsidies, were implemented. The socio-economic potential may or may not require a change in consumer preferences. Finally, even if all market, institutional, social and cultural factors whose removal is cost-effective from a societal perspective were removed, some technologies might not be widely used simply because they are still too expensive. Elimination of this requirement would therefore take us to the level of the technical potential, the maximum technologically feasible extent of GHG mitigation through technology diffusion. Moving from right to left, the figure shows that factors increase costs and reduce the savings potential of a mitigation technology.

Figure 1 presents a snapshot in time of the factors and potentials for the penetration of technologies. Over time, technological progress, discoveries of new resources and/or technologies, and cost-effective government policies and programs could eliminate some of the factors and hence move the potential lines (including the technical potential) to the right, thereby increasing the savings from a mitigation option. 
The figure also shows that transaction costs add to the cost of the mitigation option. As a market matures, the decline in transaction costs caused by learning by doing and standardization will push the cost curve lower which will increase the market penetration of a technology.

The focus of this report is on the factors affecting the realization of GHG reductions from energy efficiency. The price of energy plays a role in determining the energy savings potential, the higher the price larger the potential and vice versa. In this report, however, we do not focus on the price of electricity. The price or tariff line is seen to intersect the marginal cost curve of energy efficiency savings. Should the tariff be higher, then more of these savings would be cost effective than would be the case otherwise.

\section{Analysis of Factors Affecting CFLs and Clothes Washers}

As noted in the introductory section, we illustrate the use of our factors approach by demonstrating its application to two residential building technologies - CFLs and clothes washers. Given the scope of this project it was decided to limit analysis to one sector to reduce the number of parameters to be considered. The buildings sector was chosen in part since considerable analysis has been performed by Berkeley Lab as part of its end-use labeling and standards program. These technologies are characterized by differing levels of financial investment as well as differing degrees of portability. Thus, each technology is affected by a slightly different set of the factors enumerated in Section 3. In our analysis of costs and benefits, we have tried to use conservative values for our parameters so that the benefits of adopting the resource-efficient technologies examined will not be overstated.

\subsection{Xenergy Study on California Efficiency Potential}

Our analysis relies, in part, on a 2002 report prepared for the Energy Foundation and the Hewlett Foundation by Xenergy Inc. (Rufo and Coito, 2002) This report was designed to assess the mid-term potential of energy efficiency measures from 2002 to 2011. Measures and technologies were limited to those technologies that are currently commercially available. Thus, the potential for significant efficiency improvements from new technologies was not considered. Our report uses this analysis of California's efficiency potential as a starting point for our measure-level estimates.

The Xenergy study focuses on electricity savings from end uses in the residential, commercial, and industrial sectors. The spectrum of possible efficiency savings is divided into five classifications: technical, economic, maximum achievable, program, and naturally occurring. These categories, while similar to those described above in Section 3, make no distinction between economic and socioeconomic potentials.

The Xenergy study follows the traditional CCE methodology as described in Section 2 in which measures are assessed to determine their levelized costs per kWh saved. For any given measure, the entire state stock is treated as one homogenous entity and each measure is estimated to have a certain savings potential at a given levelized cost. These measures are then stacked to form supply curves. These curves are used to estimate economic potentials under various future energy cost scenarios. 
The Xenergy report models adoption of energy efficiency technologies in a three-step process. In the first step, the total stock of the technology is pared down to the eligible stock. This step is a function of three different factors: (1) the applicability factor, (2) the not complete factor, and (3) the feasibility factor. The first factor refers to the portion of the stock for which the efficiency measure is relevant. For example, in our analysis of resource efficient clothes washers, we had to pare down the stock of total households to those households equipped with washer facilities. The not complete factor describes the share of stock (or new sales) that does not already adopt the efficient technology in question. In other words, this is the remaining stock after the baseline share has already been taken into account. The feasibility factor reduces the stock to account for cases where the efficient technology may not physically be able to substitute for the standard technology. For example, due to the larger size of CFLs, they do not fit into all fixtures designed for incandescent bulbs. These factors reduce the penetration level but do not affect the engineering estimate of the cost of conserved energy.

The second step reduces penetration based on the level of consumer awareness. Beginning with an initial level of awareness, awareness levels respond to changes in marketing expenditures in subsequent periods. An algorithm matches awareness to the levels of this expenditure. A decay function built into this algorithm accounts for the decline in awareness that occurs over time after a marketing campaign.

In the third step, end users who are aware of a given efficiency option must decide whether to adopt. This is modeled as movement along a logistical curve that pairs adoption rate values to benefit-cost ratio values. ${ }^{3}$ Most of the factors described in Section 3 thus are treated implicitly by either the awareness or adoption functions. The last two steps make the penetration level sensitive to marketing efforts and the benefit cost ratio, which is influenced by utility rebate programs and energy prices. Thus, they are used to calculate diffusion of the efficiency measures under various program expenditure and energy cost scenarios.

\subsection{Methodology}

We examine the impact of factors on both the penetration level and the cost of conserved energy of the technology. Similar to the Rufo and Coito study, we reduce the penetration level based on several different factors, and then look at the impact of additional factors on the CCE. Figure 2 depicts in a graphic form the relationship between the conceptual potentials and factors used in Rufo and Coito (2002) and this study. The left end of the figure represents no energy savings with increasing savings moving to the right. The applicability and feasibility factors in effect delimit the stock considered and so precede the calculation of savings shown in the table. The Xenergy and Berkeley Lab definitions of the baseline or naturally occurring savings are similar except that the Xenergy definition excludes any utility or government programs, whereas we include the effect of current programs on the expected baseline savings. The program level of savings as defined in the Xenergy report is based on a series of scenarios with realistic funding levels for rebates and information campaigns. The

\footnotetext{
${ }^{3}$ Given the functional form of this logistical curve, exceedingly high CCE values are necessary to bring adoption down to near zero. Since we reduce savings estimates by the expected baseline level of adoption as a first step, adoption should fall to near zero by the time the last factor is applied. This does not occur with the CCE values we have derived. Thus, a residual level of savings above the baseline remains unexplained in these analyses.
} 
maximum achievable level is attained under the most aggressive programs possible but would still fall short of the idealized market potential, which assumes perfect information. The definitions of economic potential differ somewhat in that externalities are not accounted for in the Total Resource Cost test method. Therefore, the Xenergy economic potential does not capture quite as much savings as a societal economic definition. The technical potential is the same, except that the Berkeley Lab conception includes an intermediary socio-cultural level (as shown in Figure 1). Table 2 and Table 4 show how all of these factors are applied to each technology and provide an explanation for how we arrive at a quantitative estimate of the impact of the factor, the Rufo and Coito category that is closest to the description of a factor, and the policies and programs that may be used to target one or more factors.

Figure 2. Correspondence of Xenergy and Berkeley Lab Savings Potentials and Factors

\begin{tabular}{|c|c|c|c|c|c|c|c|}
\hline $\begin{array}{l}\text { Xenergy } \\
\text { Potentials }\end{array}$ & $\begin{array}{l}\text { Naturally } \\
\text { Occurring }\end{array}$ & Program & $\begin{array}{l}\text { Maximum } \\
\text { Achievable }\end{array}$ & \begin{tabular}{|l} 
Eco \\
Res
\end{tabular} & $\begin{array}{l}\text { nomic (Total } \\
\text { ource Cost) }\end{array}$ & Technical & \\
\hline Xenergy Factors & $\begin{array}{l}\text { Not } \\
\text { Complete }\end{array}$ & \multicolumn{2}{|c|}{ Awareness/Adoption } & \multicolumn{4}{|c|}{ Not Considered } \\
\hline $\begin{array}{l}\text { Berkeley Lab } \\
\text { Potentials }\end{array}$ & Baseline & Marke & & & $\begin{array}{l}\text { Economic } \\
\text { (Societal) }\end{array}$ & Socio-cultural & Technical \\
\hline $\begin{array}{l}\text { Berkeley Lab } \\
\text { Factors }\end{array}$ & Baseline & $\begin{array}{l}\text { Split } \\
\text { inforn }\end{array}$ & $\begin{array}{l}\text { access to } \mathrm{Cl} \\
\text { preferences, }\end{array}$ & $\begin{array}{l}\text { dit, } \\
\text { tc. }\end{array}$ & Not Consider & & \\
\hline
\end{tabular}

Note that since we have attempted to model consumer behavior in response to the consumer's perceived costs and benefits, we have performed our CCE calculations from the consumer perspective. This is similar to the approach used by Rufo and Coito except that they used avoided energy and demand costs by time period instead of customer energy rates. We have also used the same logistical curve used by Rufo and Coito to model adoption in response to the consumer benefit-cost ratio, but we have used different slope and mid-point parameters when necessary to fit our data and assumptions.

In the following subsections, we describe the application of the methodology to two residential technologies. For each of these analyses we stress that the values used for various parameters (particularly for the implicit information and preference costs) are entirely hypothetical. ${ }^{4}$ The focus of this study is less on quantitative results and more on the application of the methodological approach. A final caveat for the results described is that since the adoption function is non-linear, the sequence in which the cost-increasing factors are applied influences their relative impacts on adoption.

\subsection{Compact Fluorescent Lamps}

CFLs were first sold commercially in early 1980s. From the beginning, engineering benefitcost analyses indicated that CFLs pay for themselves and ultimately save money. Yet,

\footnotetext{
${ }^{4}$ Rigorous estimation of these values was beyond the scope of this study. However, economists have devoted considerable attention to the estimation of various implicit costs and benefits for a wide range of goods and activities. Generally, these studies have used one of two broad approaches, revealed preferences and contingent valuation (use of surveys). See Boardman et al. (1996) and references therein for a review of this literature.
} 
residential market share of CFLs remained below 1\% in the U.S. until 2000 and had only climbed to less than $3 \%$ by 2003 . For California, the share was only slightly higher until the electricity crisis in 2001 when the share jumped to about $6 \%$ for the year. Since 2001, the market share of CFLs has fallen to between $4 \%$ and $5 \%$ per year (Itron, 2004). Given the energy savings CFLs provide, their slow penetration into the residential lighting market would be difficult to explain. The high initial cost of CFLs served as a psychological factor affecting purchase and reduced the net savings due to the reduction in electricity consumption. For the first few years after their introduction into the market, CFLs cost anywhere from ten to as much as thirty times the cost of a standard light bulb. At this cost differential, consumers balked at the idea of paying so much for a product they were habituated to paying so little for. (Menanteau and Lefebvre, 2000)

In addition, analysts have noted that CFLs were far from perfect substitutes for standard incandescent bulbs. The early generation of CFLs generated many complaints from consumers, due to four aspects of the lights themselves. With incandescent bulbs, consumers are used to instant illumination, but with the early CFLs there was a significant delay between flicking the switch and the illumination of the bulb. In addition, the cycle rate of the bulbs created a noticeable flicker of the light bulbs that annoyed consumers. Color rendition was also another facet of CFLs that impeded widespread adoption since the light was bluer and colder than the light from incandescent bulbs. Finally, the large size of CFLs and their ballasts prevented their use in many standard fixtures. (Menanteau and Lefebvre, 2000) Technological improvement has eliminated or mitigated most of these factors, yet market share remains very low.

\subsubsection{Parameter Values for Calculating the CCE}

Table 1 lists the values used to calculate the initial CCE for purchasing a CFL. The costs for the bulbs were taken as fairly typical costs for bulbs in grocery or hardware stores, although CFLs can often be found for much less than $\$ 10$ in large discount stores or online. The wattages and lifetimes used are standard for these types of bulbs. Since the average length of time a fixture is used per day affects the benefits from purchasing a CFL, we based our analysis on an average use figure of 2.5 hours per day, the same figure used for the majority of residential fixtures included in the Rufo and Coito (2002) analysis. A discount rate of $15 \%$ was selected as a compromise between the $8 \%$ nominal rate used by Rufo and Coito (2002) and the higher implicit discount rates often observed in the purchase decisions of individuals. ${ }^{5}$ The CCE was calculated by using the price differential between the CFL and the present value of the eight bulbs that would be needed to replace it over a span of 8.8 years (the amount of time an 8,000 hour bulb should last at 2.5 hours per day), a total of $\$ 2.47$. The difference was annualized over the life of the bulb, yielding an initial CCE of $\$ 0.031$ per kWh saved each year (Table 2, Row 1).

\footnotetext{
${ }^{5}$ Rufo and Coito use $8 \%$ since it was the rate mandated by the CPUC for program filing by California's investorowned utilities in 2001. (Rufo and Coito, 2002)
} 
Table 1. Parameter Values for Calculating the CCE and Benefits for CFLs

\begin{tabular}{|l|c|c|c|c|c|c|}
\hline & Cost & Wattage & $\begin{array}{c}\text { Elec Cost per } \\
\mathrm{kWh}\end{array}$ & $\begin{array}{c}\text { Lifetime } \\
\text { (Hours) }\end{array}$ & $\begin{array}{c}\text { Hours of Use } \\
\text { per Day }\end{array}$ & $\begin{array}{c}\text { Discount } \\
\text { Rate }\end{array}$ \\
\hline Incandescent & $\$ 0.50$ & 75 & $\$ 0.10$ & 1,000 & 2.5 & $15 \%$ \\
\hline CFL & $\$ 10.00$ & 18 & $\$ 0.10$ & 8,000 & 2.5 & $15 \%$ \\
\hline
\end{tabular}

\subsubsection{Calculation of the Initial Stock}

Our estimate of total savings potential begins with the figure of 12.3 million California households in 2001 given in the latest Residential Energy Consumption Survey (RECS) data (U.S. EIA, 2003). To estimate the number of households in 2005, we increased the number of households by a $1.2 \%$ annual rate of growth, ${ }^{6}$ which yields nearly 12.9 million. We estimate that there are 13 fixtures per household in use for approximately 2.5 hours per day. This is the simple average of the estimated number of single-family residence (18) and multifamily residence (8) fixtures used at 2.5 hours per day as reported by Coito and Rufo (2003). From this we subtract the number of fixtures that are estimated to be using CFLs by 2005. To derive this estimate we calculated the cumulative number of CFLs purchased in the eight years (the approximate lifespan of a CFL used 2.5 hours per day) prior to 2005 using data from Itron (2004). Since CFL market share was less than or about equal to $1 \%$ prior to 2001, we used $1 \%$ as the market share from 1997 through 2000, then 6\% for 2001, and 5\% for subsequent years. The result is that by 2005, a cumulative $21 \%$ of all fixtures are assumed to be using CFLs. The removal of these fixtures from the eligible stock is equivalent to Rufo and Coito's application of what they refer to as the "not complete" factor. The remaining number of fixtures, nearly 132.8 million, represents the starting point for our analysis (Table 2, Row 1).

\subsubsection{Analysis of the Impact of Factors}

Table 2 presents a list of factors used for our analysis of CFL penetration. The factors are listed sequentially as they were applied. Each row in the table shows for each factor, its incremental effect on the CCE, the cumulative CCE, the incremental and cumulative shares of the initial eligible stock not adopting as a result of the factor, the absolute impact on reducing the number of fixtures adopting and the corresponding GHG savings, ${ }^{7}$ a brief explanation of the factor and its value, suggested policies and programs, and the analogous factor used in the Rufo and Coito (2002) analysis.

The first factor listed is not actually a barrier per se, but is rather an adjustment of eligible stock for the expected actual market share, which represents the base case. For the year 2005, we assume the trend from the previous two years remains steady at 5\%, which leaves about 130.4 million eligible fixtures to be replaced in 2005.

\footnotetext{
${ }^{6}$ This based on the average rate of projected population growth in California between 2000 and 2005. (U.S. Census Bureau, 2004)

${ }^{7}$ Avoided GHG emissions were calculated from reduced electricity consumption using the emission factor of $300.7 \mathrm{~g} \mathrm{CO}_{2} / \mathrm{kWh}$ given in California Climate Action Registry (2002).
} 
The first several factors are all deemed to affect the eligible stock of fixtures without necessarily impacting the expected costs and benefits. For example, the fact that an assumed $1 \%$ of households have their electric service included in their rent (i.e. are not separately metered) reduces the number of households considered likely to adopt CFLs since they do not benefit from the savings CFLs offer (Row 2). This is often the case for university dormitories where individual rooms are not metered. However, this has no bearing on the CCE of other households purchasing CFLs. The next factor, "lock-in," refers to the fact that due to the larger size and mass of CFLs they do not fit into all fixtures that were originally designed for incandescent bulbs (Row 4). Despite the reductions in the size of the bulbs that have occurred in recent years, it is assumed that due to various factors, CFLs still will not fit in $20 \%$ of the fixtures without some modification. ${ }^{8}$ This results in a total reduction of adopters from the eligible stock of $29 \%$. The final "costless" factor affecting the number of adopters is product availability (Row 5). For this factor we assume that approximately $20 \%$ of the population does not have convenient access to CFLs. This is based on an underlying assumption that most of the rural population, roughly $5 \%$ of the total, (U.S. EIA, 2003) and roughly $15 \%$ of the urban and suburban population do not have access to CFLs in the nearby stores where they typically shop.

The next factor is the first one that affects the CCE. It is important to keep in mind that with the introduction of a factor changing the CCE of an energy efficient product another significant change occurs in our estimation of the number of adopters. In addition to the change in CCE, we begin to use the adoption algorithm to model consumer responses to changes in the benefit-cost ratio.

The inclusion of the product lifetime uncertainty factor represents the possibility that a consumer may doubt claims about the expected lifetime of CFLs or may underestimate the impact that product lifetime has on offsetting the equivalent number of incandescent bulbs needed (Row 6). To model this factor, we reduced the expected lifetime of CFLs from 8,000 hours to 6,000 hours and recalculated the costs and benefits. The change in lifetime raises the CCE by $\$ 0.007$ and reduces the number of adopters by nearly $16 \%$.

The next three factors represent transaction costs and implicit costs. For these three factors product information cost, vendor information cost, and consumer preferences - we added $\$ 10$, $\$ 5$, and $\$ 5$ respectively to the "price" of the bulb (Rows 7,8 , and 9 ). The product information cost reflects two broad levels of awareness. One condition is the possibility that a consumer is not aware of CFLs at all. The information cost of this scenario is difficult to monetize. How much does it cost to make a consumer aware of something and to understand the benefits of buying the product? The answer may be the cost per consumer of a marketing campaign, but it is difficult to estimate the cost of successfully educating a consumer about the net savings from CFLs or other technologies whose upfront costs are higher than more standard options. The second possibility is that a consumer is vaguely aware of CFLs and the fact that they save energy but has not acquired the information necessary to accurately assess the real savings and other benefits they offer. This scenario is more easily quantified as the time cost of the

\footnotetext{
${ }^{8}$ While it is true that CFLs have been developed to fit virtually every standard screw-in fixture, certain types such as dimmable and three-way lights, are not commonly available. Moreover, some smaller lamps have shades designed to fit directly onto standard A19 bulbs.
} 
consumer looking up the information needed to make an informed choice. Our values are loosely based on the time a relatively aware consumer would need to spend to look up information on the product in question at a time cost of $\$ 20$ per hour. The additional information cost of $\$ 10$ more than doubles the CCE leading to a sharp drop in the number of adopters. The inclusion of the vendor information (or "search") cost, estimated at $\$ 5$, further reduces the adoption by another $6 \%$ of the total.

The consumer preference factor represents the fact that many consumers may simply prefer the familiar shape of incandescent bulbs as well as the warmer light they emanate (Row 9). While current models of CFLs have improved the warmth of the light, many consumers may still associate fluorescent light with the bluer light given by tube fluorescents and may not be aware of the improvements in CFL technology. For this factor, we added another \$5 to the "cost" of the CFL. This results in another $40 \%$ relative drop in adoption, leaving a residual savings of 2,209 GWh, a little less than $4 \%$ of the total estimated technical potential savings. 
Table 2. Effect of Market Factors on CFL Sales in California in 2005 (18W CFL vs. 75W Incandescent Bulb Used 2.5 Hours per Day)

\begin{tabular}{|c|c|c|c|c|c|c|c|c|c|c|}
\hline Factor & $\begin{array}{l}\text { Parameter } \\
\text { Affected }\end{array}$ & $\begin{array}{l}\text { CCE } \\
\text { Effect }\end{array}$ & $\begin{array}{l}\text { Total } \\
\text { CCE }\end{array}$ & $\begin{array}{l}\text { Penetration } \\
\text { Reduction } \\
\text { Effect }\end{array}$ & $\begin{array}{l}\text { Cumul } \\
\text { Red'n }\end{array}$ & $\begin{array}{l}\text { Adopting } \\
\text { Stock in } \\
2005\end{array}$ & $\begin{array}{l}\text { Lifetime GHG } \\
\text { Savings from } 2005 \\
\text { Purchases, k } \\
\text { tonnes } \mathrm{CO}_{2} \\
\end{array}$ & Explanation & $\begin{array}{l}\text { Policies \& } \\
\text { Programs }\end{array}$ & $\begin{array}{l}\text { Xenergy } \\
\text { Variable }\end{array}$ \\
\hline 1. Initial Stock & N/A & N/A & $\$ 0.031$ & N/A & N/A & $132,770,314$ & 18,205 & $\begin{array}{l}\text { These are the initial values } \\
\text { before factors are applied. }\end{array}$ & N/A & N/A \\
\hline $\begin{array}{l}\text { 2. Baseline } \\
\text { Share }\end{array}$ & ES & N/A & $\$ 0.031$ & $5 \%$ & $5 \%$ & $126,131,798$ & 17,295 & $\begin{array}{l}\text { The estimated California } \\
\text { market share of CFLs in } \\
2005 .\end{array}$ & N/A & $\begin{array}{l}\text { Not Complete } \\
\text { Factor }\end{array}$ \\
\hline $\begin{array}{l}\text { 3. Split } \\
\text { Incentive }\end{array}$ & ES & N/A & $\$ 0.031$ & $1 \%$ & $6 \%$ & $124,870,481$ & 17,122 & $\begin{array}{l}\text { Assumes a small number of } \\
\text { HH pay a flat fee for } \\
\text { electricity. }\end{array}$ & N/A & $\begin{array}{l}\text { Applicability } \\
\text { Factor }\end{array}$ \\
\hline $\begin{array}{l}\text { 4. Lock-In } \\
\text { (lights do not } \\
\text { fit fixture) }\end{array}$ & ES & N/A & $\$ 0.031$ & $20 \%$ & $25 \%$ & $99,896,384$ & 13,698 & $\begin{array}{l}\text { The number of fixtures that } \\
\text { do not accommodate CFLs. }\end{array}$ & N/A & $\begin{array}{l}\text { Feasibility } \\
\text { Factor }\end{array}$ \\
\hline $\begin{array}{l}\text { 5. Product } \\
\text { Availability }\end{array}$ & ES & N/A & $\$ 0.031$ & $20 \%$ & $40 \%$ & $79,917,108$ & 10,958 & $\begin{array}{l}\text { Assumes some rural } \\
\text { population and some lower } \\
\text { income urban population do } \\
\text { not have nearby stores selling } \\
\text { CFLs. }\end{array}$ & $\begin{array}{l}\text { Utility-run } \\
\text { purchase by } \\
\text { mail programs }\end{array}$ & N/A \\
\hline $\begin{array}{l}\text { 6. Lifetime } \\
\text { Uncertainty }\end{array}$ & LT & $\$ 0.007$ & $\$ 0.038$ & $16 \%$ & $49 \%$ & $67,316,135$ & 6,923 & $\begin{array}{l}\text { Lifetime reduced by two } \\
\text { thousand hours to reflect } \\
\text { uncertainty over product } \\
\text { lifetime. }\end{array}$ & $\begin{array}{l}\text { Consumer } \\
\text { education on } \\
\text { CFL testing } \\
\text { and reliability } \\
\end{array}$ & N/A \\
\hline $\begin{array}{l}\text { 7. Product } \\
\text { Information } \\
\text { Cost }\end{array}$ & $\mathrm{K}$ & $\$ 0.048$ & $\$ 0.086$ & $72 \%$ & $86 \%$ & $18,970,889$ & 1,951 & $\begin{array}{l}\text { Assumes one-half hour } \\
\text { needed (at } \$ 20 \text { time value per } \\
\text { hour) for consumers to } \\
\text { educate themselves about } \\
\text { CFLs. }\end{array}$ & \begin{tabular}{|l|} 
Consumer \\
awareness \\
campaign on \\
benefits of \\
CFLs \\
\end{tabular} & $\begin{array}{l}\text { Awareness } \\
\text { Function }\end{array}$ \\
\hline $\begin{array}{l}\text { 8. Vendor } \\
\text { Information } \\
\text { Cost } \\
\end{array}$ & $\mathrm{K}$ & $\$ 0.024$ & $\$ 0.110$ & $44 \%$ & $92 \%$ & $10,696,434$ & 1,100 & $\begin{array}{l}\text { Assumes one quarter hour } \\
\text { needed to find nearby vendors } \\
\text { with CFLs. }\end{array}$ & $\begin{array}{l}\text { Product and } \\
\text { vendor lists for } \\
\text { consumers } \\
\end{array}$ & $\begin{array}{l}\text { Awareness } \\
\text { Function }\end{array}$ \\
\hline $\begin{array}{l}\text { 9. Consumer } \\
\text { Preference, } \\
\text { Light Quality } \\
\text { \& Bulb Shape }\end{array}$ & $\mathrm{K}$ & $\$ 0.024$ & $\$ 0.134$ & $40 \%$ & $95 \%$ & $6,459,449$ & 664 & $\begin{array}{l}\text { Assigns a } \$ 5 \text { penalty to CFLs } \\
\text { to reflect consumer preference } \\
\text { for familiar incandescent light } \\
\text { and shape. }\end{array}$ & $\begin{array}{l}\text { Consumer } \\
\text { awareness } \\
\text { about CFL } \\
\text { improvements } \\
\end{array}$ & N/A \\
\hline
\end{tabular}

Notes: $\mathrm{HH}$ = households; ES = eligible stock; LT = lifetime; $\mathrm{K}$ = capital cost 


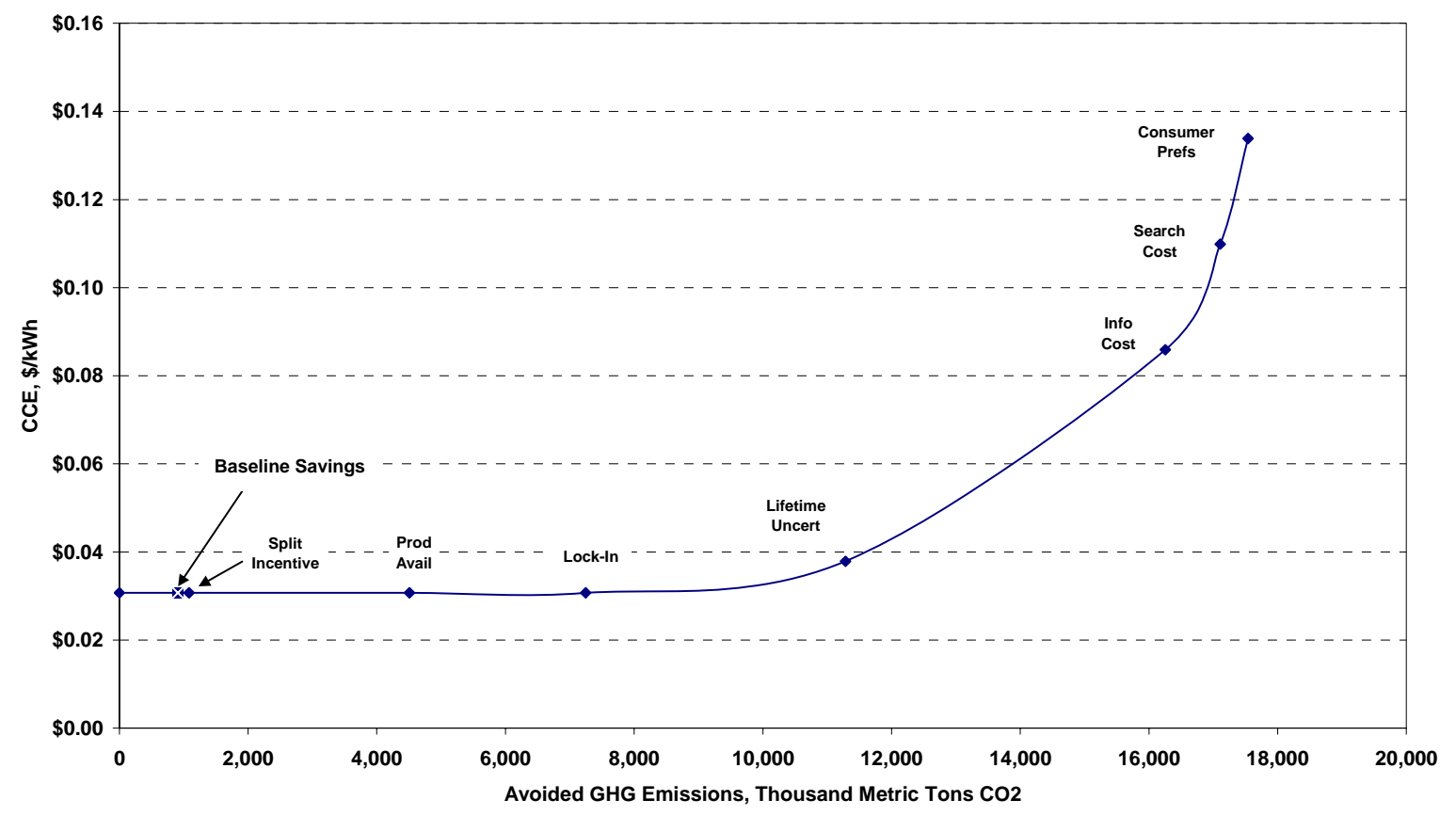

Figure 3. Supply Curve of Savings Potential from CFLs Adjusted for Impact of Factors

Figure 3 depicts the CCE and GHG savings numbers from Table 2 as a conserved energy supply curve. Unlike conventional conserved energy supply curves, which are composed of multiple measures whose quantities are unresponsive to price, this curve depicts one measure for which the expected savings (and CCE) increase as individual factors are overcome. The savings potential of each factor is calculated as the incremental change from one factor to another as shown in Table 2, with the baseline savings being the difference between the total technical potential (18,205 $\mathrm{k}$ tonnes) and the reduced savings potential accounting for baseline share shown in Row 2. Each successive point on the curve pairs the incremental difference from row to row with corresponding CCE.

CFLs face relatively few factors affecting eligible stock other than incompatible fixtures. The key factor seems to be lack of information. Given the costs and benefits of CFLs, the substantial implicit information cost must be added in order to drive market share down to current actual levels. As part of that lack of information it is also quite possible that many consumers are not aware of the improvements that have taken place in CFL technology in recent years. Thus, expanding the market share of CFLs may depend in part on overcoming biases against them due to prior consumers' experiences with earlier generations of CFLs.

Table 2 also lists the types of policies and programs that might be implemented in order to increase the market penetration of CFLs. Each factor is matched to an appropriate policy or program that effectively targets it. CFLs in the current market are clearly a cost-effective device to purchase. Yet, their market share is quite low.

We exclude the discussion of standards since they simultaneously address all of the factors affecting adoption and thus obviate the need for factor specific analysis. Due to the impact of standards on the entire consumer market, standards cannot be implemented lightly. Their use 
requires careful technical and economic analysis to ensure that benefits outweigh costs. Distributional effects also need to be considered so that any expenditure increases due to standards do not place an undue burden on lower-income consumers. CFLs, however, save money in virtually all applications, with the exception of very low-use fixtures.

It is also difficult to apply standards to the CFL market since the GHG savings comes not from an incremental improvement in the standard technology but from the adoption of an altogether different technology. Short of banning the sale of incandescent bulbs, a standard cannot be applied to the entire stock. However, the use of buildings codes to require installation of CFLs for new and remodeled homes could be extended to cover more areas of home lighting.

All of the major California utilities have some program in place to promote CFLs. All of the utilities with the exception of LADWP offer a rebate for purchasing CFLs, although LADWP does offer a rebate for certain fixtures hard-wired for CFLs. In addition, they offer a free sixpack of CFLs to customers who take advantage of their refrigerator/freezer recycling program. The other utilities all offer instant in-store rebates through specific retailers. According to our analysis, however, the price of CFLs is not, per se, the principal factor to their increased diffusion. Even at $\$ 10$ per bulb, which is much higher than either the price available at high-volume retailers or through on-line vendors, our analysis shows that CFLs reduce GHG emissions at a very low CCE. The problem primarily lies in the lack of information on the part of consumers, which suggests that aggressive education and marketing campaigns might be more effective. Addressing this lack of information can help to address several factors: lifetime uncertainty, information cost, vendor search costs, and consumer preferences.

SMUD and SDG\&E are pursuing this strategy with a more proactive approach to stimulating the market. SDG\&E is sponsoring community information events as well as lighting exchange events where customers can turn in incandescent bulbs and halogen torchieres for free CFLs and fluorescent torchieres. (SDG\&E, 2004) SMUD also has a program to target customers at area Wal-Marts to promote CFLs. (SMUD, 2004) Utilities may also address the problem of product availability by either selling CFLs directly to customers by mail or directing customers to phone-order and online distributors.

How might one use this type of analysis in a bottom-up or top-down modeling framework? The analysis highlights that merely using engineering cost analysis is likely to yield technology costs that are too low and penetration levels that are too high. The explicit inclusion of factors as illustrated above will yield cost curves that are more realistic. The analysis thus permits explicit evaluation of individual factors and the extent to which these are likely to affect engineering cost and market penetration level estimates. A modeler would then have the option of deciding the policies and programs that are likely to be implemented and estimate their impacts on the cost curve. Alternatively, a modeler may choose to run alternative scenarios of policy and program intervention to evaluate their impacts. Similarly, transaction costs that are described in the Appendix could be explicitly added to the cost of carbon reduction of a technological option in a model. 


\subsection{Resource Efficient Clothes Washers}

The next technology chosen was resource efficient clothes washers. For washers, we say "resource efficient" rather than energy efficient since efficient clothes washers save significant amounts of water as well as energy. Indeed, most of the energy savings is due to avoided energy use from reduction of hot water consumption.

Both the physical size of washers and the significant price premium between resource efficient washers and standard vertical axis washers introduce new factors to be considered beyond those used in the CFL analysis. First, although not a barrier per se, is the fact that washers will generally last 10 to 15 years and will not be replaced before their useful life is over. Thus, only a fraction of the stock is turning over during any given year. Second, many households do not have washer and dryer hook-ups. Residents in these households must use either on-site facilities or laundromats and thus have no control over the choice of washers that will be purchased. Eligible stock is thus limited to households with washer and dryer hook-ups. Finally, major appliances are often provided in many rental units. This arrangement introduces the split incentive factor, since the renters' desire to reduce energy and water consumption expenditures conflicts with the property owners desire to provide the appliances at the lowest possible cost.

\subsubsection{Parameter Values for Calculating the CCE}

The values used to calculate the initial CCE for resource efficient clothes washers are shown in Table 3. The cost of standard washers is taken as a typical price for the low-end models offered from online retailers such as Sears or Best Buy. The cost, as well as the expected annual unit electricity consumption (UEC), of the resource efficient model is based on the Kenmore 44042 from Sears.com. For the electricity and gas UECs of clothes washers using gas-heated water, some assumptions had to be made. Other values were adapted either from those given in the Energy Star washer savings calculator or derived from calculation therein. (U.S. EPA, 2004) The washer savings calculator assumes that about $10 \%$ of the total electricity consumption of a washer using electric heated water is consumed for mechanical energy by the washer itself. Thus, we used the same ratio for our standard model. However, we assume that the ratio is not accurate for resource efficient washers since so much less electricity is used for water heating. We assume that the ratio is closer to $20 \%$. The natural gas and water consumption values are rounded values from the Energy Star calculator.

The price of water comes from East Bay Municipal Utility District (EBMUD). (EBMUD, 2004) These values include the charges for wastewater treatment as well as City of Berkeley sewer service (City of Berkeley, 2004). The higher value for high-income households assumes that larger houses and additional end-uses lead to higher water consumption, which is charged at a higher incremental rate. For low-income households it is assumed about half of water is provided at the subsidized rate. Due to the differences in the cost of water, as well as power, it was decided to segment the market into low, middle, and high-income groups. These groups are defined simply as the lowest, middle two, and highest quartiles of households.

Electricity and natural gas costs are from the 2004 values for PG\&E. (PG\&E, 2004a; PG\&E, 2004b) For electricity, these values assume that low-income households receive power at the 
average of the Tier 1 and Tier 2 (baseline and 100 to 130\% above baseline) CARE rates, that middle-income households marginal savings are taken from the standard Tier 2 rate, and that high-income households savings are taken from the Tier $3(131 \%+$ above baseline) rate due to larger houses and more end-uses. The values for natural gas follow similar assumptions. The low-income rate is the average of CARE baseline and excess rates, middle-income is the average of the standard and excess baseline rates, and high-income is the excess rate. All values for water and energy consumption are derived from an underlying assumption of 392 loads a year as proscribed by the official DOE test procedure. (U.S. DOE, 2004)

Table 3. Parameter Values for Calculating the CCE for Resource Efficient Washers

\begin{tabular}{|c|c|c|c|c|c|c|c|c|c|c|c|c|c|c|c|c|c|}
\hline & \multirow[t]{2}{*}{ Cost } & \multirow{2}{*}{$\begin{array}{c}\text { UEC } \\
\text { w/ } \\
\text { Elec } \\
\text { WH }\end{array}$} & \multicolumn{2}{|c|}{$\begin{array}{l}\text { UEC w/ } \\
\text { Gas WH }\end{array}$} & \multirow{2}{*}{$\begin{array}{c}\text { Annual } \\
\text { Water } \\
\text { Consum } \\
\text { ption }\end{array}$} & \multicolumn{3}{|c|}{$\begin{array}{c}\text { Energy Cost, Elec per } \\
\text { kWh }\end{array}$} & \multicolumn{3}{|c|}{$\begin{array}{c}\text { Energy Cost, Gas per } \\
\text { Therm }\end{array}$} & \multicolumn{3}{|c|}{ Water Cost } & \multicolumn{3}{|c|}{ Discount Rate } \\
\hline & & & Elec & Gas & & LI & MI & $\mathrm{HI}$ & LI & MI & $\mathrm{HI}$ & LI & MI & HI & LI & MI & HI \\
\hline \begin{tabular}{|l|} 
Standard \\
Washer \\
\end{tabular} & $\$ 400$ & 600 & 60 & 36 & 14,000 & $\$ 0.10$ & $\$ 0.14$ & $\$ 0.18$ & $\$ .742$ & $\$ .952$ & $\$ 1.062$ & $\$ .0056$ & $\$ .0067$ & $\$ .0072$ & $20 \%$ & $15 \%$ & $10 \%$ \\
\hline \begin{tabular}{|l|} 
Resource \\
efficient \\
Washer
\end{tabular} & $\$ 680$ & 218 & 40 & 18 & 7,000 & $\$ 0.10$ & $\$ 0.14$ & $\$ 0.18$ & $\$ .742$ & $\$ .952$ & $\$ 1.062$ & $\$ .0056$ & $\$ .0067$ & $\$ .0072$ & $20 \%$ & $15 \%$ & $10 \%$ \\
\hline
\end{tabular}

The use of washers as one of the end-use options we have examined also offers an example where the inclusion of non-energy benefits has a crucial impact on the cost-effectiveness of the technology. Although the cost of tap water per gallon is trivial, the fact that washers are responsible for such a large quantity of residential consumption means that for households with gas water heating, the annual monetary savings from avoided water consumption outweigh those from reduced energy consumption. The initial weighted average CCE for all households when water savings are not counted is $\$ 0.136$, compared to $\$ 0.049$ when they are included.

\subsubsection{Calculation of the Initial Stock}

The calculation of the eligible stock of washers sold in 2005 starts with U.S. shipment data from the Association of Home Appliance Manufacturers' Fact Book 2000. (AHAM, 2000) Since we take 12 years as the average lifetime of a home washer, we looked at domestic shipments for 1993 as an estimate of the number of washers that will need to be replaced in 2005. We then multiplied this figure by the California share of U.S. population (U.S. Census Bureau, 2002) to estimate the number of washers sold in California in 1993. This results in an estimate of 717,661 washer retirements in 2005. For the number of new washers sold in 2005, we used population estimates from the Census for 2005 and calculated the average annual rate of growth from 2000 to 2005 (U.S. Census Bureau, 2004). This rate was used to estimate the additional households that would be needed to house the population growth from 2004 to 2005. This figure is 146,892. Multiplying this by the percentage of households with washers from RECS 2001 - approximately 68\% (U.S. EIA, 2003), leaves 100,316 washers sold for new housing units. 
In addition to the differences in the costs of water and power among income groups, another reason for segmenting the market is that higher income households are assumed to have a higher share of residency in units with washer/dryer hook-ups, either in single family residences (SFRs) or larger, more modern multifamily residences (MFRs). Thus, the share of low-income households assumed to have in-house laundry facilities was reduced by $30 \%$, and the share of high-income households was increased by 30\%. Middle-income households were assumed to have in-house laundry facilities at the average rate.

Since heating water by natural gas costs less than heating water electrically, the type of water heater has a large impact on the monetary savings due to resource efficient washers. Thus, total washer sales also split into two different categories according to whether the water heater used in the household is natural gas or electric. Since a split of water heater types by income was not available, the statewide figure of $85 \%$ was used for all income groups. (U.S. EIA, 2003) Resource efficient washers are significantly more cost-effective for those using electricheated water due to the higher cost per unit of energy for electricity. For example, although the initial CCEs for washers using gas and electric-heated water in high-income households are virtually the same ( $\$ 0.016$ and $\$ 0.017$ respectively), the benefit-cost ratios differ significantly due to the reduced benefit of saving a cheaper fuel (1.4 versus 2.5). Due to the predominance of gas water heating in California residences (U.S. EIA, 2003), the total CCE and penetration results are determined mostly by the calculations for gas water heating.

\subsubsection{Analysis of the Impact of Factors}

Table 4 lists all factors affecting washers, their impacts on CCE and reduction of adoption, as well as policies that might be appropriate for each factor. The CCE and penetration effects have been aggregated from the water heater and income categories in order to simplify the presentation of results and to show the total impact on the entire population. In general, resource efficient clothes washers are more cost-effective for higher-income households due to the higher imputed costs for water and power as well as the lower discount rates.

The total amount of lifetime $\mathrm{CO}_{2}$ emissions that would be avoided if all washers purchased in California in 2005 were comparable to the resource efficient model we examine rather than standard models would be 1,012 thousand metric tons $\mathrm{CO}_{2}$ (Table 4, Row 1). ${ }^{10}$ We assume that the share of resource efficient washers among new sales in 2005 will not have changed much from the most recent figure we found, which is 12\% for 2001. (CEE, 2002) Accounting for this baseline share leaves 887 thousand metric tons $\mathrm{CO}_{2}$ that can potentially be achieved by various policies and programs (Row 2). The initial CCE is only $\$ 0.041$, an extremely costeffective CCE on average. ${ }^{11}$ However, this average CCE hides significant differences among the income groups. While the middle-income group is close to the average, the CCE for high-

\footnotetext{
${ }^{10}$ Avoided $\mathrm{CO}_{2}$ emissions were calculated using an emission factor of $300.7 \mathrm{~g} \mathrm{CO}_{2} / \mathrm{kWh}$ and $52.78 \mathrm{~g}$ $\mathrm{CO}_{2}$ /thousand Btu for natural gas. (California Climate Action Registry, 2002)

${ }^{11}$ Note that in order for figures to be given in comparable units, the heat content of the natural gas used for water heating was converted to $\mathrm{kWh}$ using a conversion factor of 3,412 Btu per $\mathrm{kWh}$. However, more final energy is required to heat water with natural gas due to the waste heat lost in combustion gases and other factors. Therefore, the values for natural gas were reduced to their useful energy content using a factor of 0.62 (based on gas water heater efficiency standards in place from 1991 to 2004) in order to make the CCE values less dependent on fuel choice. (U.S. GPO, 2001)
} 
income households is much lower at $\$ 0.018$. Low-income households have a much higher CCE of $\$ 0.076$ due to the lower energy and water prices they pay, as well as their higher discount rate.

Both the split incentive and product availability factors substantially reduce the number of households that will buy resource efficient washers (Rows 3 and 4). To assign values to these factors we had to make several assumptions. The split incentive factor assumes that most rental households with washers have the washers provided by the property owner. We also assume that the higher the income the less an impact split incentives will have due to a larger share of residents in SFRs. The product availability factor is similar to that used for CFLs with an assumption that resource efficient washers are somewhat less widely available than CFLs. The capital access factor was modeled in a very simplified manner since this factor would be extremely difficult to quantify more precisely. We have simply assumed that for every $\$ 100$ of additional cost between a resource efficient washer and a standard model, a certain percent of the population will not be able to obtain financing for it. This percentage varies among the income groups: $10 \%$ for low-income households and $5 \%$ for middle-income households. High-income households are assumed not to face capital constraints.

The subsequent factors are analogous to those described for CFLs. Either the performance is decreased below expected values to reflect lower consumer confidence in unfamiliar products (Rows 6 and 7), or various implicit costs are added to the sale price of the machine (Rows 8 through 10). For performance uncertainty, energy consumption was increased by $15 \%$. This results in an increase in the weighted average CCE of $17 \%$ and a reduction in the adopting stock of $14 \%$. For lifetime uncertainty, three years were shaved off the expected lifetime of the resource efficient washer. This increases the CCE by over $46 \%$ and reduces adoption by $28 \%$. Significant implicit costs had to be added to the machines in order to reduce adoption to near actual levels. For lower-income households we assigned a $\$ 60$ product information cost, and for middle- and high-income households we used $\$ 50$. The addition of the information cost reduced total adoption by another $10 \%$. For transaction costs and consumer preferences, we used $\$ 40$ for all consumers. Together, these two barriers reduced adoption by another $8 \%$, leaving 89 thousand metric tons $\mathrm{CO}_{2}$ of unexplained residual savings. This is about $9 \%$ of the estimated savings from adoption by the total initial stock. Consumer preferences for standard washers may be due in part to the greater number of models on the market offering a wide range of features as well as to the familiarity consumers have with standard top-loader washers. Of the factors subject to policy solutions, the policy prescriptions offered suggest that the biggest obstacles to increasing consumer acceptance of resource efficient washers are information factors of various sorts.

However, one of the larger factors, which is obscured by the aggregation of results in Table 4, is simply the cost-effectiveness of resource efficient washers. For the low-income group using gas water heating, resource efficient washers do not pay for themselves. In other words, the benefit-cost ratio is less than one. Likewise, for the middle-income group using gas water heating, the initial benefit-cost ratio is only slightly greater than one. This is due to the fact that the price of gas per unit of final energy is much lower than electricity, equaling a little over $\$ 0.03$ for a kilowatt-hour's worth of heat. These households would probably require a rebate in addition to information to begin buying resource efficient washers in significant numbers. 
In addition to the analysis of the factor impacts on CCE and rate of adoption, Table 4 also lists the policies or programs that we believe are well suited to overcoming each factor. Most of the recommended programs are consumer awareness and education campaigns. Rebates, however, may be effective in attracting consumers to resource efficient washers who are not necessarily capital-constrained. Reducing the cost difference between the two types of washers would also serve to lessen consumer concerns over whether the benefits of owning resource efficient washers compensate for the price premium paid.

As for CFLs, we do not list minimum performance standards, which depending on their stringency, have the potential to achieve virtually all of the estimated potential savings shown in Table 4. Rigorous washing machine standards are set to take effect in California beginning in 2007, becoming stricter in 2010. These standards will significantly improve water and energy efficiency for washers sold in California. Based on our rough analysis, this standard should be cost-effective for most classes of consumers in California. For low-income households using gas water heating, resource efficient washers may not pay for themselves, assuming that these households receive reduced rates for their water and power. These estimates are very sensitive to two factors: the initial cost of the resource efficient washers and the number of loads the machines are used for each week. If the cost of a base model resource efficient washer drops just $10 \%$ below the price used in our example, they would be cost-effective for all customers. ${ }^{12}$ Resource efficient washers may also not be cost-effective for some smaller households that use their machines fewer than eight times per week. Keep in mind, these estimates are calculated purely from the customer perspective and do not take into account the true opportunity cost of the water consumed.

Several of the major California utilities have existing programs to promote the purchase of resource efficient clothes washers. With the exception of Southern California Edison, all of them offer rebates between $\$ 75$ and $\$ 125$ depending on the efficiency of the washer. ${ }^{13}$ LADWP offers a top rebate of $\$ 150$ of combined energy and water rebates for the purchase of certain washers (LADWP, 2004). SDG\&E has a washer rebate, but the program has already distributed all of its money for 2004. Most of the utilities have fact sheets on their web sites that provide some information on the benefits and features of resource efficient washers. A few utilities also provide energy analyzers on their websites to enable users to more easily assess the costs and benefits of purchasing resource efficient washers.

\footnotetext{
${ }^{12}$ Due to economies of scale and technological progress, the price of many energy efficient appliances has often fallen after the application of minimum performance standards (Dale et al., 2002).

${ }^{13}$ The level of the rebate depends on whether the washer is a Tier 1 or Tier 2 and higher washer. A description of the tiers and their efficiency levels is available from CEE (2004).
} 
Table 4. Effect of Market Factors on Resource Efficient Washing Machine Sales in California

\begin{tabular}{|c|c|c|c|c|c|c|c|c|c|c|}
\hline Factor & $\begin{array}{l}\text { Parameter } \\
\text { Affected }\end{array}$ & $\begin{array}{l}\text { CCE } \\
\text { Effect }\end{array}$ & $\begin{array}{l}\text { Cumulative } \\
\text { CCE }\end{array}$ & $\begin{array}{l}\text { Penetration } \\
\text { Reduction } \\
\text { Effect }\end{array}$ & $\begin{array}{l}\text { Cumul } \\
\text { Red'n }\end{array}$ & $\begin{array}{l}\text { Stock } \\
\text { Adopting } \\
\text { in } 2005\end{array}$ & $\begin{array}{l}\text { Lifetime GHG } \\
\text { Savings from } \\
2005 \text { Purchases, } \\
\text { k tonnes } \mathrm{CO}_{2}\end{array}$ & Explanation & $\begin{array}{l}\text { Policies \& } \\
\text { Programs }\end{array}$ & \begin{tabular}{|l|} 
Xenergy \\
Variable
\end{tabular} \\
\hline 1. Initial Stock & N/A & N/A & $\$ 0.043$ & N/A & N/A & 817,977 & 1,012 & $\begin{array}{l}\text { These are the initial values before } \\
\text { factors are applied. }\end{array}$ & N/A & N/A \\
\hline $\begin{array}{l}\text { 2. Baseline } \\
\text { Share }\end{array}$ & ES & N/A & $\$ 0.043$ & $12 \%$ & $12 \%$ & 716,957 & 887 & $\begin{array}{l}\text { Nat'l share of RE washers among } \\
\text { new sales in } 2001 \text { was } 12 \% \text {. Our } \\
\text { allocation assumes LI HH } \\
\text { unwilling to buy at current } \\
\text { premium. Allocation between MI } \\
\text { and HI results in } 12 \% \text { overall } \\
\text { share. }\end{array}$ & N/A & $\begin{array}{l}\text { Not Complete } \\
\text { Factor }\end{array}$ \\
\hline $\begin{array}{l}\text { 3. Split } \\
\text { Incentive }\end{array}$ & ES & N/A & $\$ 0.043$ & $23 \%$ & $32 \%$ & 552,359 & 683 & $\begin{array}{l}\text { \# rental HH in CA is slightly less } \\
\text { than } 50 \% \text {. Our allocation } \\
\text { assumes lower shares of rental } \\
\text { HH w/ higher incomes. Half of } \\
\text { rental HH assumed to have either } \\
\text { no in-unit W/D hook-up or to be } \\
\text { already furnished w/ W/D. }\end{array}$ & N/A & $\begin{array}{l}\text { Applicability } \\
\text { Factor }\end{array}$ \\
\hline $\begin{array}{l}\text { 4. Product } \\
\text { Availability }\end{array}$ & ES & N/A & $\$ 0.043$ & $24 \%$ & $48 \%$ & 422,555 & 523 & $\begin{array}{l}\text { Assumes rural population (10\%) } \\
\text { has no access to RE washers, and } \\
15 \% \text { of sub/urban population has } \\
\text { no easy access. }\end{array}$ & N/A & N/A \\
\hline $\begin{array}{l}\text { 5. Access to } \\
\text { Capital }\end{array}$ & ES & N/A & $\$ 0.043$ & $12 \%$ & $54 \%$ & 372,510 & 461 & $\begin{array}{l}\text { Calculated as } 10 \% \text { of LI HH } \\
\text { cannot obtain financing for every } \\
\$ 100 \text { premium for RE washers } \\
\text { and } 5 \% \text { for MI HH. }\end{array}$ & $\begin{array}{l}\text { Rebates or } \\
\text { low-interest } \\
\text { loans for } \\
\text { qualifying } \\
\text { HH. }\end{array}$ & N/A \\
\hline $\begin{array}{l}\text { 6. Energy } \\
\text { Consumption } \\
\text { Uncertainty }\end{array}$ & S & $\$ 0.007$ & $\$ 0.051$ & $14 \%$ & $61 \%$ & 321,591 & 427 & $\begin{array}{l}\text { Machine's rated consumption } \\
\text { increased } 15 \% \text { to reflect } \\
\text { possibility that machine does not } \\
\text { perform as well as under test } \\
\text { conditions. This decreases } \\
\text { savings and thus adds to CCE. }\end{array}$ & $\begin{array}{l}\text { Consumer } \\
\text { education on } \\
\text { optimal } \\
\text { washer } \\
\text { settings. }\end{array}$ & N/A \\
\hline
\end{tabular}




\begin{tabular}{|c|c|c|c|c|c|c|c|c|c|c|}
\hline Factor & $\begin{array}{l}\text { Parameter } \\
\text { Affected }\end{array}$ & $\begin{array}{l}\text { CCE } \\
\text { Effect }\end{array}$ & $\begin{array}{l}\text { Cumulative } \\
\text { CCE }\end{array}$ & $\begin{array}{l}\text { Penetration } \\
\text { Reduction } \\
\text { Effect }\end{array}$ & $\begin{array}{l}\text { Cumul } \\
\text { Red'n }\end{array}$ & \begin{tabular}{|l|} 
Stock \\
Adopting \\
in 2005
\end{tabular} & \begin{tabular}{|l|} 
Lifetime GHG \\
Savings from \\
2005 Purchases, \\
k tonnes $\mathrm{CO}_{2}$ \\
\end{tabular} & Explanation & $\begin{array}{l}\text { Policies \& } \\
\text { Programs }\end{array}$ & $\begin{array}{l}\text { Xenergy } \\
\text { Variable }\end{array}$ \\
\hline $\begin{array}{l}\text { 7. Lifetime } \\
\text { Uncertainty }\end{array}$ & $\mathrm{LT}$ & $\$ 0.023$ & $\$ 0.074$ & $28 \%$ & $72 \%$ & 231,209 & 340 & $\begin{array}{l}\text { Lifetime reduced by three years } \\
\text { to reflect uncertainty over } \\
\text { product lifetime. }\end{array}$ & $\begin{array}{l}\text { Consumer } \\
\text { education on } \\
\text { washer } \\
\text { testing and } \\
\text { durability. } \\
\end{array}$ & N/A \\
\hline $\begin{array}{l}\text { 8. Product } \\
\text { Information } \\
\text { Cost }\end{array}$ & $\mathrm{K}$ & $\$ 0.034$ & $\$ 0.110$ & $35 \%$ & $82 \%$ & 149,999 & 184 & $\begin{array}{l}\text { Add } \$ 50 \text { information cost for MI } \\
\text { and HI consumers to educate } \\
\text { themselves about RE washers } \\
\text { and } \$ 60 \text { for LI consumers (due to } \\
\text { lower percentage with internet } \\
\text { access). }\end{array}$ & $\begin{array}{l}\text { Consumer } \\
\text { awareness } \\
\text { campaign on } \\
\text { benefits of } \\
\text { RE washers. }\end{array}$ & $\begin{array}{l}\text { Awareness } \\
\text { Function }\end{array}$ \\
\hline $\begin{array}{l}\text { 9. Vendor } \\
\text { Information } \\
\text { Cost }\end{array}$ & $\mathrm{K}$ & $\$ 0.026$ & $\$ 0.137$ & $26 \%$ & $86 \%$ & 110,907 & 120 & $\begin{array}{l}\text { Adds } \$ 40 \text { of time/hassle cost to } \\
\text { find nearby vendors with RE } \\
\text { washers. }\end{array}$ & $\begin{array}{l}\text { Product and } \\
\text { vendor lists } \\
\text { for } \\
\text { consumers. }\end{array}$ & $\begin{array}{l}\text { Awareness } \\
\text { Function }\end{array}$ \\
\hline $\begin{array}{l}\text { 10. Consumer } \\
\text { Preference, } \\
\text { Features }\end{array}$ & $\mathrm{K}$ & $\$ 0.026$ & $\$ 0.165$ & $24 \%$ & $90 \%$ & 84,044 & 89 & $\begin{array}{l}\text { Assigns a } \$ 40 \text { penalty to } \mathrm{RE} \\
\text { washers to reflect lower variety } \\
\text { of models and features that } \\
\text { consumers may desire. }\end{array}$ & $\begin{array}{l}\text { Consumer } \\
\text { awareness on } \\
\text { range of RE } \\
\text { models. }\end{array}$ & N/A \\
\hline
\end{tabular}

Notes: $\mathrm{HH}=$ households; $\mathrm{LI}=$ low income; $\mathrm{MI}=$ middle income; $\mathrm{HI}=$ high income; $\mathrm{ES}=$ eligible stock; LT = lifetime; $\mathrm{S}=$ (cost) savings; $\mathrm{K}=$ capital cost; $\mathrm{RE}=$ resource efficient 
Figure 4 depicts the results shown in Table 4 above as a conserved energy supply curve. We have also added the curve we calculated for the case where the water savings are not taken into account. These curves demonstrate the importance of water savings in making resource efficient washers an attractive investment for the average residential user. Note that the potentials for each measure do not line up on the $\mathrm{X}$ axis since the relative impacts of the measures on the benefit-cost ratios differ in the two cases. The curves also help to illustrate that a large share of the potential savings is affected by factors that have little or no impact on the CCE. According to our rough estimates, over $70 \%$ of the post-baseline savings are impeded by the first four factors, after which the CCE is still below $\$ 0.05$.

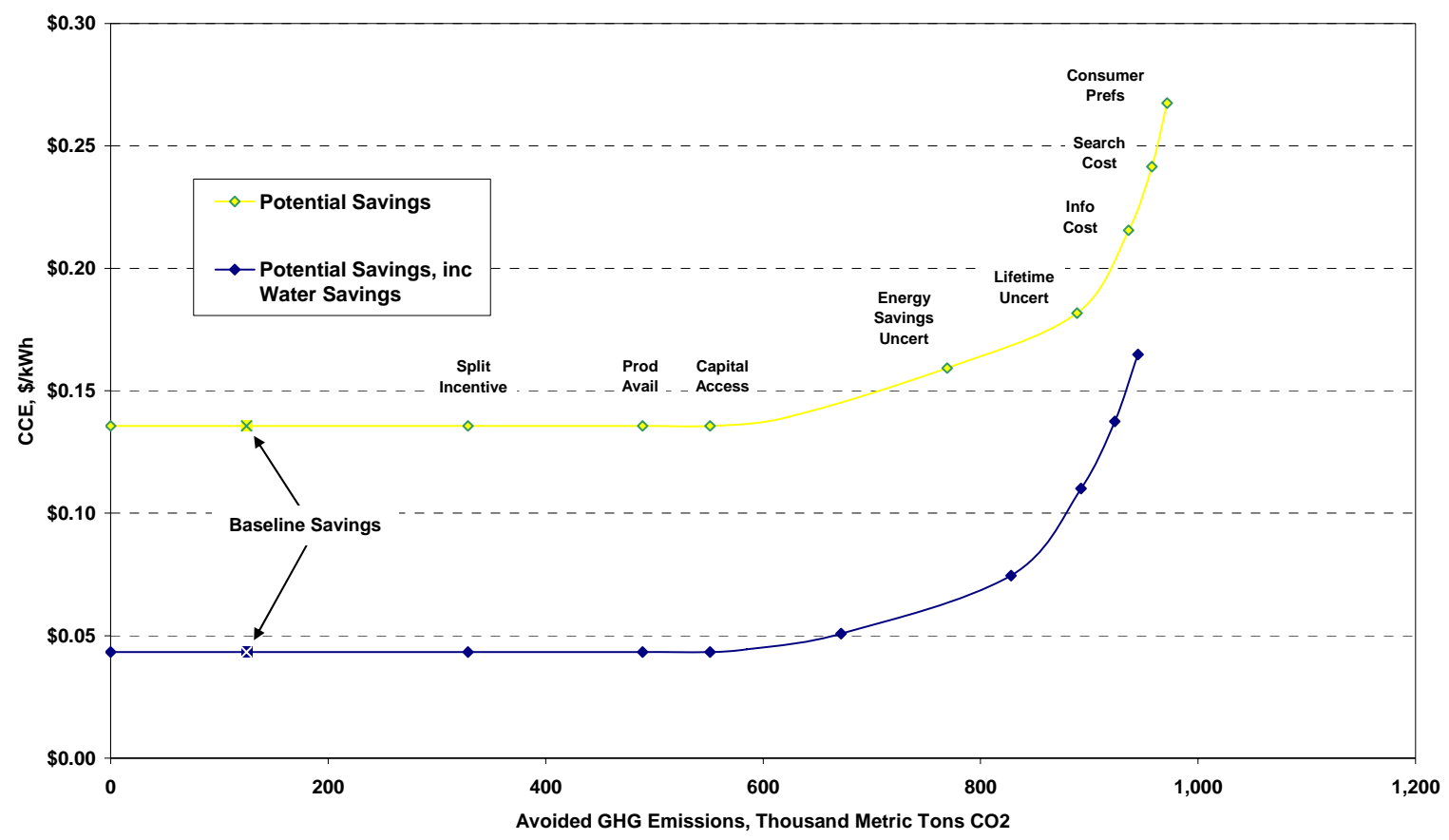

Figure 4. Supply Curve of Savings Potential from Resource Efficient Washers Adjusted for Impact of Market Factors

\section{Discussion}

The previous analyses illustrate how a factor-specific approach can be applied to estimates of the costs and savings potentials of various end-use technologies. This approach offers an alternative to the traditional method of constructing CES curves where each measure is given one CCE based on engineering estimates and one savings potential based on the application of the measure to the eligible stock. The power of a more disaggregated approach is that savings potentials may be estimated more accurately by accounting for the implicit costs and other factors that impede adoption of new technologies. By making the treatment of each factor explicit, a more realistic sense of the trade-offs involved between savings and the costs of 
overcoming the factors affecting savings can be incorporated into economic models that attempt to account for the effect of energy efficiency policies.

While we have attempted to sketch out the basic approach, there are some obstacles that limit our analysis. To some extent there are methodological questions for which no definitive answers exist. For example, what is the "right" private discount rate? To what extent does the private discount rate vary by income? There are also questions regarding the definition of information costs and how they should be estimated. Information costs may be defined as the cost of the effort for a consumer to educate himself about the features, costs, and benefits of a given technology. The cost of programs to provide information to consumers about an energy efficient technology is an alternative approach to estimating information costs. However information costs are defined, they are difficult to quantify, as are the impacts of consumer preferences for various aspects of end-use technologies. We have determined these values using informed judgment of time spent in seeking information and its opportunity cost.

With further research, it should be possible to more accurately estimate the impacts of individual factors on various measures. Additionally, if consumer responsiveness to policies and programs targeting these factors can be more accurately measured, policies could be more realistically modeled using disaggregated parameters for modeling climate mitigation policy.

\section{Conclusions}

We have seen that many factors may impede the diffusion of resource efficient technologies that are otherwise cost-effective. Some of these factors affect the adoption of technologies without changing their costs or benefits, while others carry hidden or implicit costs. In the customary methods of constructing conserved energy supply curves, individual measures are modeled as providing a certain amount of savings at a fixed CCE. However, the amount of savings one can expect from a measure is not completely independent of cost. Although we have not explicitly attempted to model consumer response to policies and programs, the analysis of supply curves presented in this report could be incorporated into economic models to make the treatment of policies and programs more explicit and, hopefully, more precise.

For all measures, high implicit information costs were required to reduce adoption of the measures we examined to near current levels. While some factors such as split incentives, product availability, and lock-in may reduce adoption significantly, it is difficult to explain the rest of the gap between cost-effective potential and current penetration rates. Cognitive limitations on gathering and processing information may account for much of this gap. This suggests that government interventions to reduce information and transaction costs can significantly increase diffusion of resource efficient products.

A recent statistical analysis of DSM programs at over 300 utilities finds that DSM programs have not been as successful at reducing customer energy demand as widely reported (Loughran and Kulick, 2004). The authors conclude that DSM expenditures, the majority of which have been spent on financial incentives, could be better spent on collecting and disseminating information, particularly if targeted toward customers on the edge of investing in energy efficient equipment. Consumer preferences for non-energy attributes of standard options, such as light quality for lamps or washing options for washers, might also account for 
some of the efficiency gap, but recent improvements in CFLs and the greater number of resource efficient models of washers have eliminated many of the differences between standard and resource efficient options.

The use of minimum performance standards offers a powerful policy remedy to overcoming virtually all of the barriers that we have enumerated. Unlike information collection and dissemination programs, standards also provide a means of resolving the split-incentive barrier. However, the application of standards requires careful analysis, and in some cases low-income households may need financial assistance to comply.

Our analysis of the two measures examined shows the potential for large lifetime GHG savings from resource efficient products purchased in 2005. Since a large share of the stock of incandescent bulbs turns over every year due to their short lifetimes, CFLs offer by far the largest opportunity for lifetime savings from 2005 sales. Our figures show that after taking the baseline portion of sales into account, if all the incandescent bulbs burning approximately 2.5 hours per day were replaced in 2005, lifetime savings above baseline would be 17,295 $\mathrm{k}$ tonnes $\mathrm{CO}_{2}$ at a $\mathrm{CCE}$ of $\$ 0.031$ per $\mathrm{kWh}$ saved. Clothes washers sold in 2005 could save roughly $887 \mathrm{k}$ tonnes $\mathrm{CO}_{2}$ at a CCE of $\$ 0.043$, but they are affected by a significant split incentive barrier that may characterize over $20 \%$ of the potential stock. This measure demonstrates the importance of including non-energy benefits when calculating the CCE. When water savings are not taken into account, the CCE climbs to $\$ 0.136$. It is important to keep in mind that even though the CCE for installing resource efficient washers in homes with gas water heating is similar to that for electric water heating, the greater cost per unit of useful electricity makes the benefit-cost ratio for consumers with electric water heating much higher.

More research will be required to fully develop the application of this approach for use in economic models. As other analysts have had to for previous analyses, we have had to make informed estimates for many of the monetary values attached to specific factors. Further efforts will be needed to quantify the various types of implicit costs and to understand how to integrate them into economic models. 


\section{Appendix: Transaction costs}

In this section, we provide an in-depth discussion of transaction costs, which constitute an important subset of diffusion factors. Broadly, transaction costs can encompass several of the factors described above related to the cost of acquiring, assessing, and using information (Golove and Eto, 1996). Here we are using "transaction costs" in a narrower sense - the costs related to participation in an emissions trading or energy efficiency program requiring certification of savings.

Transaction costs arise in the trading of emissions in a market for GHG emissions, and in the implementation of policies and programs for energy efficiency. In this report, we review the transaction costs of emissions trading in emerging carbon markets. The first cut at understanding the scope of the carbon market distinguishes between 1) trade in emission allowances which exist by virtue of a domestic or limited territorial cap on emissions and 2) project-based trades where buyers and sellers collaborate to create a project to reduce emissions. Within each system, buyers and sellers may participate on a voluntary basis either with or without the intention of compliance with future targets on emissions reductions. Certain project-based initiatives aim to encourage GHG reductions, like the Global Environmental Facility (GEF) as a general environmental goal, or to experiment with the Kyoto compliance infrastructure (e.g. AIJ) but do not result in bankable or tradable credits.

\subsection{Allowance emissions trading}

A number of allowance markets operating under a cap and trade scheme are emerging. The International Emissions Trading Association (IETA) website provides a complete list of allowance markets and extensive information on the emissions trading in general.

There are three sources of transaction costs in allowance emissions trading. First, costs are incurred in establishing the scheme; second, brokers who facilitate trades incur costs; and third, preparation and monitoring costs are incurred by entities that participate in the scheme. The first type of cost may be incurred by a government department such as in the case of the UK trading scheme described below or by a private entrepreneur in the case of the Chicago Climate Exchange. The second type of cost is incurred by brokers and may be estimated from the fess charged by brokers and any additional cost for trading on an exchange. For instance, for the UK Emissions Trading Scheme (UK ETS) the UK National Audit Office reports that brokers have charged a rather low fee of $2 \%$ per transaction (National Audit Office, 2004). The UK ETS scheme has reported prices of emissions allowances that varied from a peak of $\$ 22.5$ to $\$ 4.5$ per tonne of carbon dioxide or $\$ 82.5$ to $\$ 16.5$ per t Ceq. A $2 \%$ fee would amount to a charge of $\$ 0.33-1.65$ per t Ceq. for brokerage services alone. For the Chicago Climate Exchange, there is a one time initiation fee and an annual dues structure and a cost to register the baseline with National Association of Security Dealers (NASD) and have the emissions reduction verified by Det Norske Veritas (DNV). Table 5 shows the key features of selected trading and project based schemes, including past, existing and planned. 
Table 5. Selected emissions trading and project based schemes

\begin{tabular}{|c|c|c|c|c|c|c|}
\hline Country/company & Start Date & Participants & $\begin{array}{l}\text { Mandatory/ } \\
\text { Voluntary }\end{array}$ & $\begin{array}{l}\text { Allowance } \\
\text { or Project } \\
\text { based }\end{array}$ & Coverage & $\begin{array}{l}\text { Project } \\
\text { registration } \\
\text { status }\end{array}$ \\
\hline \multicolumn{7}{|l|}{ Current or past } \\
\hline $\begin{array}{l}\text { UK Emissions } \\
\text { Trading Scheme }\end{array}$ & 2002 & $\begin{array}{l}\text { All entities, except electricity } \\
\text { generators }\end{array}$ & Voluntary & Allowance & $\begin{array}{l}\text { All six Kyoto } \\
\text { GHGs }\end{array}$ & \\
\hline Denmark & $\begin{array}{l}\text { 2001, } \\
\text { closed } 2003\end{array}$ & Eight electricity companies & Mandatory & Allowance & $\mathrm{CO}_{2}$ only & \\
\hline $\begin{array}{l}\text { Chicago Climate } \\
\text { Exchange }\end{array}$ & Oct. 2003 & $\begin{array}{l}14 \text { companies and } \\
\text { organizations at launch; } \\
\text { includes offset projects }\end{array}$ & Voluntary & $\begin{array}{l}\text { Allowance } \\
\text { and project }\end{array}$ & $\begin{array}{l}\text { All six Kyoto } \\
\text { GHGs }\end{array}$ & \\
\hline $\begin{array}{l}\text { BP Internal company } \\
\mathrm{CO}_{2} \text { trading }\end{array}$ & $\begin{array}{l}1998-2000 \\
\text { trial period; } \\
\text { closed } 2002\end{array}$ & $\begin{array}{l}\text { All business units, each had } \\
\text { individual allowance }\end{array}$ & $\begin{array}{l}\text { Voluntary/ } \\
\text { Mandatory } \\
\text { for } \\
\text { individual } \\
\text { units }\end{array}$ & Allowance & $\begin{array}{l}\mathrm{CO}_{2} \text { and } \mathrm{CH}_{4} \text {, } \\
\text { excluding } \\
\text { emissions } \\
\text { from } \\
\text { purchased } \\
\text { power and } \\
\text { heat }\end{array}$ & \\
\hline $\begin{array}{l}\text { Shell Tradable } \\
\text { Emissions Permits } \\
\text { System }\end{array}$ & $\begin{array}{l}\text { 2000, } \\
\text { closed } 2002\end{array}$ & $\begin{array}{l}\text { Six business units, based in } \\
\text { Australia, Canada, Europe, } \\
\text { and the US }\end{array}$ & Voluntary & Allowance & $\mathrm{CO}_{2}$ and $\mathrm{CH}_{4}$ & \\
\hline $\begin{array}{l}\text { Hesse -Tender } \\
\text { (Germany) }\end{array}$ & 2003 & Six companies & Voluntary & Project & $\mathrm{CO}_{2}$ & \\
\hline $\begin{array}{l}\text { Canadian Domestic } \\
\text { Emissions Trading }\end{array}$ & & $\begin{array}{l}\text { Member companies in } \\
\text { Partnerships for Climate } \\
\text { Action }\end{array}$ & Voluntary & Allowance & $\mathrm{CO} 2$ & $\begin{array}{l}\text { Partnerships } \\
\text { for Climate } \\
\text { Action }\end{array}$ \\
\hline $\begin{array}{l}\text { Dutch ERUPT and } \\
\text { CERUPT Programs }\end{array}$ & 2000 & $\begin{array}{l}\text { Renewable energy (solar, } \\
\text { wind, hydro etc), Fuel switch } \\
\text { (replacement of CO2-intensive } \\
\text { fuels by fuels generating less } \\
\text { pollution, Energy efficiency, } \\
\text { Waste processing, } \\
\text { Afforestation/reforestation }\end{array}$ & Voluntary & Project & $\begin{array}{l}\text { All six Kyoto } \\
\text { GHGs }\end{array}$ & JI and CDM \\
\hline $\begin{array}{l}\text { World Bank PCF and } \\
\text { Bio-carbon Fund }\end{array}$ & 1999 & As above & Voluntary & Project & $\begin{array}{l}\text { All six Kyoto } \\
\text { GHGs }\end{array}$ & JI and CDM \\
\hline $\begin{array}{l}\text { Global Environment } \\
\text { Facility }\end{array}$ & 1991 & $\begin{array}{l}\text { All signatories to the } \\
\text { UNFCCC }\end{array}$ & NA & NA & $\begin{array}{l}\text { No GHG } \\
\text { trading but } \\
\text { accounts for } \\
\text { GHG } \\
\text { reductions }\end{array}$ & \\
\hline $\begin{array}{l}\text { Activities } \\
\text { Implemented Jointly } \\
\text { (AIJ) }\end{array}$ & 1995 & $\begin{array}{l}\text { All signatories to the } \\
\text { UNFCCC }\end{array}$ & Voluntary & Project & $\begin{array}{l}\text { No GHG } \\
\text { trading but } \\
\text { accounts for } \\
\text { GHG } \\
\text { reductions }\end{array}$ & UNFCCC \\
\hline Climate Trust & 1997 & Unrestricted & Voluntary & Project & $\mathrm{CO}_{2}$ & \\
\hline \multicolumn{7}{|l|}{ Proposed } \\
\hline European Union & 2005 & $\begin{array}{l}\text { Industry, electricity } \\
\text { generators, and combustors > } \\
20 \mathrm{MW} \text { size }\end{array}$ & Mandatory & $\begin{array}{l}\text { Allowance } \\
\text { and project }\end{array}$ & $\mathrm{CO}_{2}$ & \\
\hline Japan & 2005 & Not known & Voluntary & & Not known & \\
\hline Norway & 2005 & Selected industrial processes & Mandatory & & $\mathrm{CO}_{2}$ & \\
\hline $\begin{array}{l}\text { Australia, New South } \\
\text { Wales }\end{array}$ & 2003 & $\begin{array}{l}\text { Electricity generators and } \\
\text { retailers }\end{array}$ & Mandatory & Allowance & $\mathrm{CO}_{2}$ & \\
\hline
\end{tabular}

Source: Based on information derived from the UK National Audit Office (2004), various websites and general market information studies. 


\subsection{Project-based emissions trading}

Project-based emissions trading entails several steps that begin with project identification; validation of the baseline and of the additionality of its emissions reductions; implementation of the project; monitoring, evaluation and verification of the reductions; and certification and eventual registration of reductions with an entity that would grant the credits commensurate with the reductions. In addition to the buyers (investors) and sellers (project developers) of emissions reductions, there are several key players and institutions that are engaged in this process. The services of third party monitors, verifiers, and certifiers are sought in cases where independent evaluations are required or the project participants lack the skills required to perform these tasks. If credits are to be granted, the governmental, nongovernmental or private administrative agency under which credits are bought and sold has a key role to play in setting the standards and rules for the trade. If the credits are to be traded across countries, states, or other administrative and legal boundaries, two or more governments may be involved in approving the transaction. In the current emerging market, emissions trading is not always the norm, and GHG reductions may occur with the intent to gain experience with implementation of the steps, other than certification, that are outlined above.

The project-based emissions trading for pre-Kyoto compliance by far is the largest $\mathrm{CO}_{2}$ market (Lecocq and Capoor, 2003). The Kyoto Protocol provides the main impetus behind project-based trades, which in addition to domestic and international emissions trading under cap and trade schemes is another option for reducing greenhouse gas emissions that count towards an emissions target. Project-based mechanisms under Kyoto include the projects dubbed Joint Implementation, meaning that one country listed in Annex B of the Kyoto Protocol, mainly a list of developed countries, can establish a project to reduce emissions in another Annex B country, as specified in Article 6 of the KP. Efforts to bring JI projects on line have been encouraged by the Activities Implemented Jointly (AIJ) project run by the UNFCCC as a pilot phase for JI projects. JI includes projects such as the Dutch Certified Emissions Reduction Unit Purchasing Tender (CERUPT) and Emissions Reduction Unit Purchasing Tender (ERUPT) programs that invest heavily in the Baltic states of Estonia, Lithuania and Latvia.

The second project-based mechanism under KP is the CDM as specified in Article 12 of the Kyoto Protocol. The key difference between CDM and JI is the identity of the partners and the additional requirement of sustainable development. CDM projects occur between entities in an Annex B (developed) country and a developing country. Thus CDM can serve as a vehicle to foster technology transfer and additional investment through a climate change project in a developing country. The additional requirement of incorporating a "sustainable development" component to the project makes the procedures for CDM approval more stringent. The CDM system envisions the creation of several institutional elements involved in the trade of Certified Emissions Reductions (CERs). First are the operational entities that can become qualified under the CDM office to certify emission reductions. Second is the designated National Authority or country office in a developing, non-Annex B country to process CDM projects in that country. Third is the executive board which supervises CDM. In addition, CDM projects are required to fund adaptation projects. Streamlining the functioning

of these institutions by designing standardized rules and procedures will facilitate transactions and thereby reduce transaction costs. 
In addition, in countries which have not agreed to participate in the KP such as the United States, private companies and other entities may invest in projects either to meet national or state emissions requirements or position themselves for the future international marketplace. As a result a number of companies have entered the market as brokers. These include Cantor Fitzgerald, Trexler and Associates, and Econergy.

The sources of transaction costs in project-based trading include the costs of setting up an entity to administer the trade, the buyers' and sellers' cost of due financial and environmental diligence, and the administrative cost borne by the host country government and the registry. The first type of administrative costs is borne by an entity such as Senter International for the Dutch projects or the PCF for the World Bank projects. These are borne by the Dutch government and the PCF contributors respectively. The buyers' and sellers' cost of due diligence include the cost of validation, monitoring, and verification and these will vary depending on the procedures established by the investor government and/or the CDM. In addition, there may be costs associated with seeking approval for the project and registering its GHG emissions reductions. The PCF has reported its costs for preparing a project-specific baseline study and determining environmental additionality to be $\$ 20,000$ per project.

Table 6. Transaction costs reported in selected studies

\begin{tabular}{|c|c|c|c|c|c|}
\hline Report & $\begin{array}{c}\text { Data } \\
\text { Source }\end{array}$ & $\begin{array}{c}\# \\
\text { Observations }\end{array}$ & \begin{tabular}{|c|} 
Transaction \\
Cost Categories
\end{tabular} & Project Type & $\begin{array}{l}\text { Transaction Cost } \\
\text { Estimates }\end{array}$ \\
\hline $\begin{array}{l}\text { Fichtner et al. } \\
\text { (2003) }\end{array}$ & AIJ & 64 & $\begin{array}{l}\text { Technical } \\
\text { assistance, } \\
\text { follow-up, } \\
\text { administration, } \\
\text { reporting }\end{array}$ & $\begin{array}{l}32 \text { Energy efficiency } 27 \\
\text { renewable energy } \\
3 \text { forestry } \\
1 \text { afforestation } \\
1 \text { agriculture }\end{array}$ & $\$ .05-261 / \mathrm{t} \mathrm{CO}$ \\
\hline $\begin{array}{l}\text { Michaelowa et al. } \\
\text { (2003) }\end{array}$ & $\begin{array}{l}\text { Ecosec } \\
\text { urities }\end{array}$ & 2 & Not available & $\begin{array}{l}\text { Gas plant } \\
\text { Biomass plant }\end{array}$ & $\begin{array}{l}\$ 0.65-\$ 1.53 / \mathrm{CO}_{2} * \\
\$ 0.87-\$ 2.40 / \mathrm{tCO}_{2} *\end{array}$ \\
\hline $\begin{array}{l}\text { Michaelowa et al. } \\
\text { (2003) }\end{array}$ & AIJ & 51 & $\begin{array}{l}\text { Technical } \\
\text { assistance, } \\
\text { follow-up, } \\
\text { administration, } \\
\text { reporting }\end{array}$ & RE, EE, Mix & $\begin{array}{l}\$ 0.16- \\
\$ 15.5 / \mathrm{tCO}_{2} *\end{array}$ \\
\hline $\begin{array}{l}\text { Michaelowa et al. } \\
\text { (2003) }\end{array}$ & PCF & 4 & $\begin{array}{l}\text { Negotiation, } \\
\text { approval, BL, } \\
\text { monitoring, } \\
\text { verification, } \\
\text { validation }\end{array}$ & Agriculture, Electricity & $\$ .02-\$ .09 / \mathrm{CO}_{2} *$ \\
\hline
\end{tabular}

*Assume an exchange rate of 8 Swedish krona per US dollar

Table 6 shows a comparison of transaction costs of climate change projects reported by some recent studies. Both Michaelowa et al. (2003) and Fichtner et al. (2003) find a scale economies phenomenon, meaning that transaction costs decrease with increases in tC delivered. Neither study considers total production and transaction costs in calculating the average cost of production as output increases, so that it is uncertain if economies of scale hold when all costs are included. Fichtner also found that renewables had greater transaction 
costs as a percentage of total project costs than energy efficiency projects. Michaelowa et al. (2003) surveyed a number of studies and sources of data. They echo the points made earlier that transaction cost analysis in the case of the emerging international carbon emissions reduction market should consider who bears transaction costs, when those costs accrue, risk consideration and institutional setting. Because of the apparent economies of scale effect on transaction cost, they suggest a threshold amount of minimum size of projects, below which projects are not viable unless special rules or subsidies are made available.

Even this brief description of the carbon market reveals a complex network of players and institutions operating under a nascent market environment. Different regulatory frameworks with varying requirements exist for current or eventual trade and hence are used for different purposes. As a consequence, the actual product traded, the carbon emissions reduction, is not a homogenous product and may not be tradeable across regulatory regimes. These differences in turn affect the price at which the product is traded. It is important to note these differences to identify what is being transacted and the extent to which transactions can be compared. Because of the different rules governing each regulatory regime, the emissions reductions are not necessarily transferable from one regulatory regime to another. Therefore, while the GHG reduction efforts are motivated by international recognition of climate change, there are a number of regional, local, national and international markets rather than one continuous market. 


\section{References}

AHAM (Association of Home Appliance Manufacturers), 2000. "Fact Book 2000.” Washington DC: AHAM.

Bardach, E., 2000. A Practical Guide for Policy Analysis: The Eightfold Path to More Effective Problem Solving. New York: Chatham House Publishers

Blumstein, C., Kreig, B., Schipper, L., and York, C., 1980. “Overcoming Social and Institutional Barriers to Energy Efficiency.” Energy 5(4):355-72.

Boardman, A.E., Greenberg, D.H., Vining, A.R., and Weimer, D.L., 1996. Cost-Benefit Analysis: Concepts and Practice. Upper Saddle River, NJ: Prentice-Hall, Inc.

Boero, G., Clarke, R. and Winters, L. 1991. The macro-economic consequences of controlling greenhouse gasses: A survey. Department of the Environment, UK.

California Climate Action Registry, 2002. General Reporting Protocol.

http://198.104.131.213/docs/PROTOCOLS/general_reporting_protocol_102102.pdf

CEE (Consortium for Energy Efficiency), 2002. "Drought Relief: Resource efficient Clothes

Washers can Help.” http://www.cee1.org/resrc/press/dr_press_kit.pdf

CEE, 2004. “CEE Residential Clothes Washer Initiative: High-Efficiency Specifications.”

http://www.cee1.org/resid/seha/rwsh/reswash_specs.pdf

City of Berkeley, 2004. "Sewer Service Fees.”

http://www.ci.berkeley.ca.us/pw/sewers/sewfees.html

Coito F. and Rufo M., 2003. California statewide Commercial Sector Natural Gas Energy

Efficiency Potential Study. Vol. 1 of 2. Study ID \#SW061. Prepared for Pacific Gas \&

Electric Company. Oakland, Calif.: KEMA-XENERGY Inc.

Dale, L., Antinori, C., McNeil, M., and McMahon, J.E., 2002. "Retrospective Evaluation of

Declining Prices for Energy Efficient Appliances.” LBNL-50114

http://eappc76.lbl.gov/tmacal/docs/50114_dale_aceee02.pdf

EBMUD (East Bay Municipal Utility District), 2004. “Complete Rates, Charges, and Fees.”

http://www.ebmud.com/about_ebmud/financial_information/fy05_rates,_charges,_fees_ and_rents/fy05_rates_all.pdf 
Eto, J., Prahl, R., and Schlegel, J., 1997. A scoping study on energy-efficiency market transformation by California utility DSM programs. Berkeley, CA: Lawrence Berkeley National Laboratory LBNL-39058

Fichtner, W., Graehl, S., and Rentz, O., 2003. The Impact of Private Investor's Transaction Costs on the Cost of Effectiveness of Project-Based Kyoto Mechanisms. Climate Policy 3 (3): 249-252.

Golove, W. H. and Eto, J., 1996. Market barriers to energy efficiency: a critical reappraisal of the rationale for public policies to promote energy efficiency. Berkeley, CA: Lawrence Berkeley National Laboratory LBL-38059

Itron, 2004. “California Lamp Report 2003.” http://www.calmac.org/publications/Lighting2003final_07152004.pdf

Jaffe, A. and Stavins R., 1994a. "The Energy Paradox and the Diffusion of Conservation Technology.” Resource and Energy Economics. 16(2): 91-122.

Jaffe, A. and Stavins, R., 1994b. ‘The Energy-Efficiency Gap: What Does it Mean?” Energy Policy. 22(10): 804-810. Johnson, F. and R. Bowie 1994. 'Transaction Costs, Energy Efficiency and Institutional Design.” 17th Annual International Energy Conference: Conference Proceedings. Cleveland, OH: International Association for Energy Economics.

Koomey, J., and A. Sanstad 1994. 'Technical Evidence for Assessing the Performance of Markets Affecting Energy Efficiency.” Energy Policy. 22(10): 826-832.

Koomey, J., A. Sanstad, and L. Shown 1995. Magnetic Fluorescent Ballasts: Market Data, Market Imperfections, and Policy Success. Lawrence Berkeley Laboratory Report No. LBL-37702. Berkeley, C.A.: Lawrence Berkeley Laboratory.

Koomey, J., 1986. A Simplified Spreadsheet Model for Assessing the Load and Energy Impacts of Demand-Side Programs for Selected Residential Appliances. Master's Project Thesis, Energy and Resources Group, University of California, Berkeley.

Koomey, J., 1990. Energy Efficiency Choices in New Office Buildings: An Investigation of Market Failures and Corrective Policies. PhD Thesis, Energy and Resources Group, University of California, Berkeley.

Krause, F., Busch, J.F., and Koomey, J.G., 1993. "Carbon Reduction Costs in New England's Power Sector." Contemporary Policy Issues. 9(2): 100. 
Krause, F., Haites, E., Howarth, R., and Koomey, J., 1993. Energy Policy in the Greenhouse. Volume II, Part 1. Cutting Carbon Emissions: Burden or Benefit?: The Economics of Energy-Tax and Non-Price Policies. El Cerrito, CA: International Project for Sustainable Energy Paths.

LADWP (Los Angeles Dept. of Water and Power), 2004. "High-Efficiency Clothes Washer Rebate Program.” http://www.ladwp.com/ladwp/cms/ladwp000399.jsp

Lecocq, F. and Capoor, K. 2003. State and Trends of the Carbon Market, 2003. PCF Plus Research, World Bank, December, Washington DC.

Loughran, D. S. and Kulick, J., 2004. Demand-side management and energy efficiency in the United States. The Energy Journal 25 (1): 19 - 41.

Meier, A., 1982. “Supply Curves of Conserved Energy.” Berkeley, CA: Lawrence Berkeley National Lab. LBL-14686

Menanteau, P. and Lefebvre, H., 2000. Competing technologies and the diffusion of innovations: the emergence of energy-efficiency lamps in the residential sector. Research Policy 29 (3), 375-389.

Michaelowa, A., Stronzik, M., Eckermann, F. and Hunt, A., 2003. Transaction costs of the Kyoto mechanisms. Climate Policy 3 (3): 261-278.

PG\&E (Pacific Gas \& Electric), 2004a. “Residential Electric Tariff Rates: September 1, 2004 to Present.” http://www.pge.com/tariffs/ResElecCurrent.xls

PG\&E (Pacific Gas \& Electric), 2004b. “Residential Gas Tariff Rates: January 1, 2004 to Present.” http://www.pge.com/tariffs/Res_Current.xls

Reddy, A.K.N., 1991. Barriers to Improvements in Energy Efficiency. Energy Policy 19, 953961.

Ruderman, H., Levine, M., and McMahon, J., 1987. “The Behavior of the Market for Energy Efficiency in Residential Appliances including Heating and Cooling Equipment.” The Energy Journal 8(1): 101-124.

Rosenfeld A. 1999. The Art of Energy Efficiency: Protecting The Environment with Better Technology. Ann. Rev. Energy Environ. 24: 33-82.

Rufo, M. and Coito, F., 2002. “California’s Secret Energy Surplus: The Potential for Energy Efficiency.” San Francisco, CA: The Energy Foundation and The Hewlett Foundation. http://www.ef.org/documents/Secret_Surplus.pdf 
SDG\&E (San Diego Gas \& Electric), 2004. "Events Schedule.” http://www.sdge.com/residential/upcomingevents.pdf

Sathaye, J., Bouille et al., 2001. Barriers, opportunities, and market potential of technologies and practices. In Climate Change 2001: Mitigation, (Eds., Metz, B., Davidson, O., Swart, R., and Pan, J.) Cambridge University Press for the Intergovernmental Panel on Climate Change.

Sathaye J., Ghirardi A. and Schipper L., 1987. Energy Demand in Developing Countries: A Sectoral Analysis of Recent Trends. Annual Review of Energy.

Sathaye J. and Ketoff A., 1991. CO2 Emissions from Major Developing Countries: Better Understanding the Role of Energy in the Long Term. The Energy Journal, January.

Sathaye J., Schipper L. and Levine M., 1986. Growth in LDC oil demand: Implications and opportunities for the US. Presentation to William F. Martin, Deputy Secretary, US Department of Energy, Washington DC.

Schumacher, Katja and Jayant Sathaye, 2000: Carbon Emissions Trends for Developing Countries and Countries with Economies in Transition. Quarterly Journal of Economic Research, No. 4, Special Issue: Energy Structures Past 2000, Berlin. LBNL-44546

SMUD (Sacramento Municipal Utility District), 2004. "Compact fluorescent bulbs.” http://www.smud.com/residential/saving/cfl.html

U.K. National Audit Office, 2004. The UK emissions trading scheme: A new way to combat climate change. Ordered by the House of Commons,

U.S. Census Bureau, 2002. "Table CO-EST2001-12-06 - Time Series of California Intercensal Population Estimates by County: April 1, 1990 to April 1, 2000.” http://www.census.gov/popest/archives/2000s/vintage_2001/CO-EST2001-12/COEST2001-12-06.html

U.S. Census Bureau, 2004. "Projections of the Total Populations of States: 1995 - 2005." http://www.census.gov/population/projections/state/stpjpop.txt

U.S. DOE (Dept. of Energy), 2004. http://www.eere.energy.gov/femp/technologies/eep_clothes_washers.cfm

U.S. EIA (Energy Information Administration, Dept. of Energy), 2003. "Residential Energy Consumption Survey 2001, Table HC2-7a." 
http://www.eia.doe.gov/emeu/recs/recs2001/hc_pdf/hous-char/hc2-

7a_4popstates2001.pdf

U.S. EPA (Environmental Protection Agency), 2004. "Washer savings calculator.”

http://www.energystar.gov/index.cfm?c=clotheswash.pr_clothes_washers

U.S. GPO (Government Printing Office), 2001. "Energy Conservation Program for Consumer Products: Energy Conservation Standards for Water Heaters.” Federal Register 66 (11): 4473 - 4497. http://frwebgate.access.gpo.gov/cgi-bin/getdoc.cgi?dbname =2001_register \&docid =01-1081-filed.pdf

Worrell, E., Laitner, J., Ruth, M., and Finman, H., 2003. Productivity benefits of industrial energy efficiency measures. Energy 28:1081-1098 